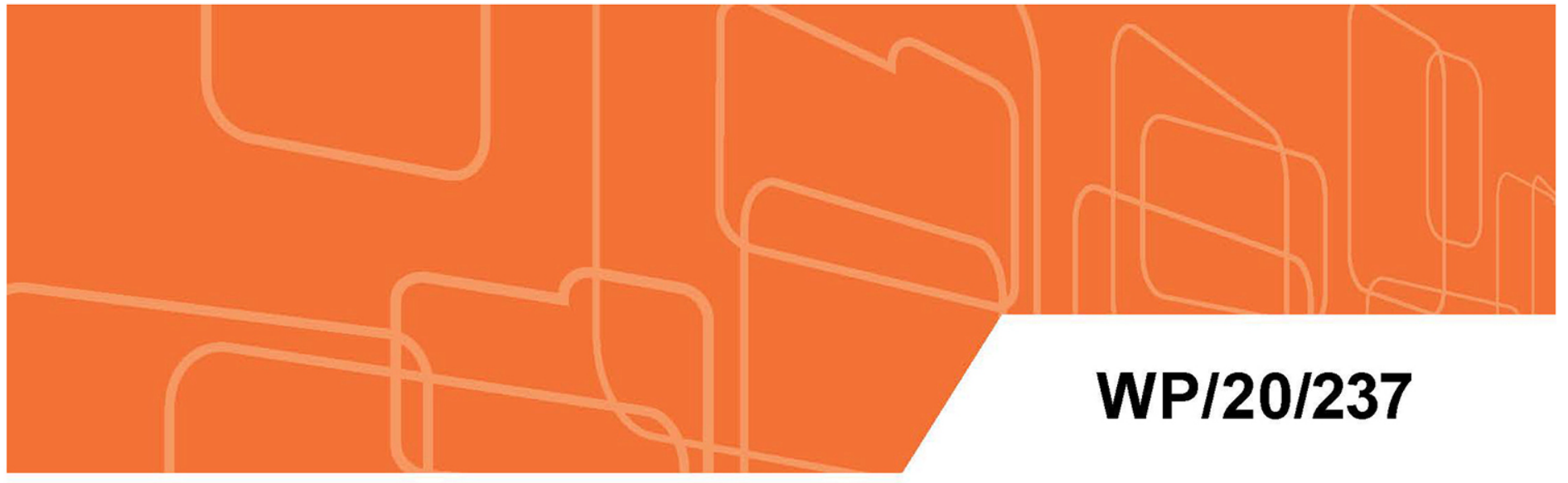

IMF Working Paper

\title{
Pre- and Post-GFC Policy Multipliers
}

by Sam Ouliaris and Celine Rochon

IMF Working Papers describe research in progress by the author(s) and are published to elicit comments and to encourage debate. The views expressed in IMF Working Papers are those of the author(s) and do not necessarily represent the views of the IMF, its Executive Board, or IMF management.

I N T E R N A T I O N A L M O N 


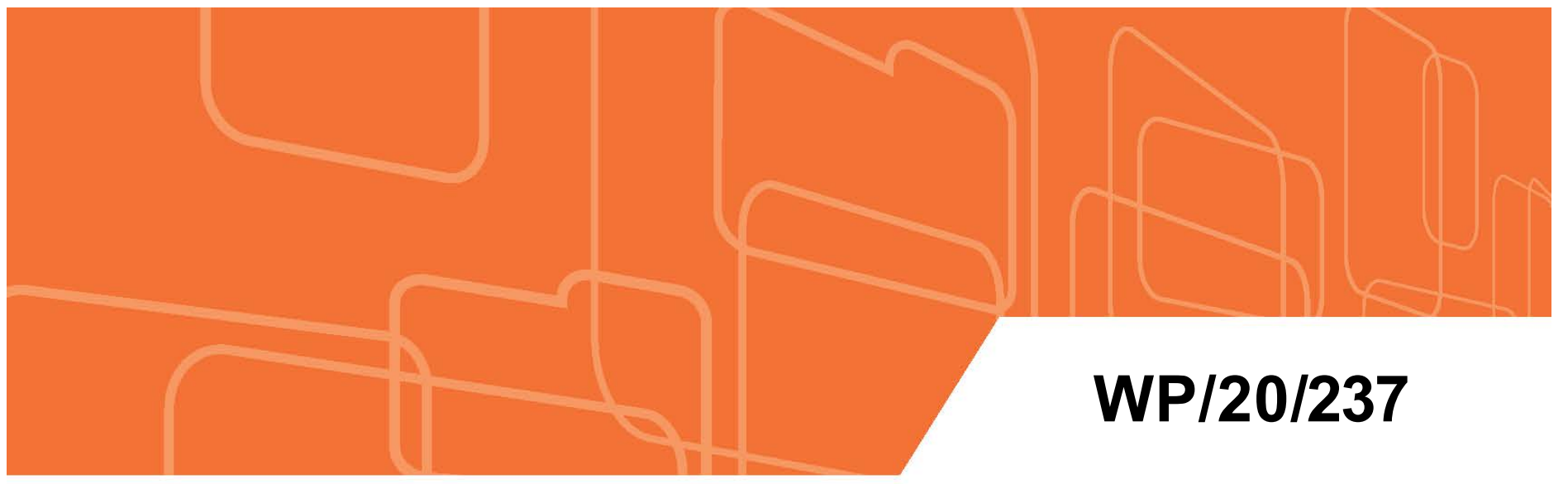

\title{
IMF Working Paper
}

\author{
Pre- and Post-GFC Policy Multipliers
}

by Sam Ouliaris and Celine Rochon

IMF Working Papers describe research in progress by the author(s) and are published to elicit comments and to encourage debate. The views expressed in IMF Working Papers are those of the author(s) and do not necessarily represent the views of the IMF, its Executive Board, or IMF management.

I N T E R N A T I O N A L M O N E T A R Y F U N D 


\title{
IMF Working Paper
}

Institute for Capacity Development

Pre- and Post-GFC Policy Multipliers

Prepared by Sam Ouliaris and Celine Rochon

Authorized for distribution by Norbert Funke

November 2020

\begin{abstract}
IMF Working Papers describe research in progress by the author(s) and are published to elicit comments and to encourage debate. The views expressed in IMF Working Papers are those of the author(s) and do not necessarily represent the views of the IMF, its Executive Board, or IMF management.
\end{abstract}

\begin{abstract}
This paper estimates the change in policy multipliers in the U.S. relative to their pre-2008 financial crisis levels using an augmented Blanchard-Perotti model to allow for the dynamic effects of shocks to the central bank balance sheet, real interest rates and debt levels on economic activity. Given the elevated debt level and significantly larger central bank balance sheet in the U.S. after 2008, the paper estimates the likely impact of new stimulus packages. We find that expenditure multipliers have fallen post-2008 crisis because of higher government debt, implying that the effectiveness of fiscal policy has declined. The analysis also investigates the impact of quantitative easing. The results suggest that it is beneficial, but requires sizable balance sheet interventions to lead to noticeable effects on real GDP. The results are used to assess the impact of the policy packages to address COVID-19. Because of rising debt stocks, dealing with a crisis is becoming more and more costly despite the current low interest rate environment.
\end{abstract}

JEL Classification Numbers: E60, E62, E63, C51

Keywords: fiscal multipliers, structural VAR, financial crisis (GFC) Author's E-Mail Address: crochon@imf.org, sam.ouliaris@gmail.com 


\section{INTRODUCTION}

G7 countries responded promptly to the 2008 global financial crisis by using a mix of economic policies, particularly expansionary fiscal and accommodative monetary policies. They also complemented these measures with structural policies designed to address the slowdown in productivity and other macro critical issues, including climate change. Countries now facing the COVID-19 pandemic are implementing both fiscal and monetary policy measures to support the real economy, in the form of transfer schemes to households and corporates, coordinated central bank actions via swap lines arrangements, liquidity facilities, and actions to support lending to households and businesses.

While expansionary policies helped to resolve the 2008 financial crisis, they may have also reduced the ability of $\mathrm{G} 7$ countries to address future slowdowns using fiscal and monetary policies. Specifically, the size and effectiveness of future countercyclical fiscal measures could be constrained by elevated debt levels that, with only one exception among G7 countries, increased during the last cyclical upswing (Figure 1). The fiscal constraint is also compounded by structural developments such as ageing populations. Likewise, future monetary policy could be constrained by the relatively low level of nominal interest rates and the sheer size of central bank balance sheets (Figure 2). Though aggressive fiscal and monetary policies allowed for a consistent and effective response to the 2008 financial crisis, they also increased external imbalances within the G7. Together with the rise in public debt, this has increased the risk of sudden and uncoordinated relative price adjustments, particularly through the exchange rate channel.

Figure 1. G7 Countries' Public Debt (\% of GDP)

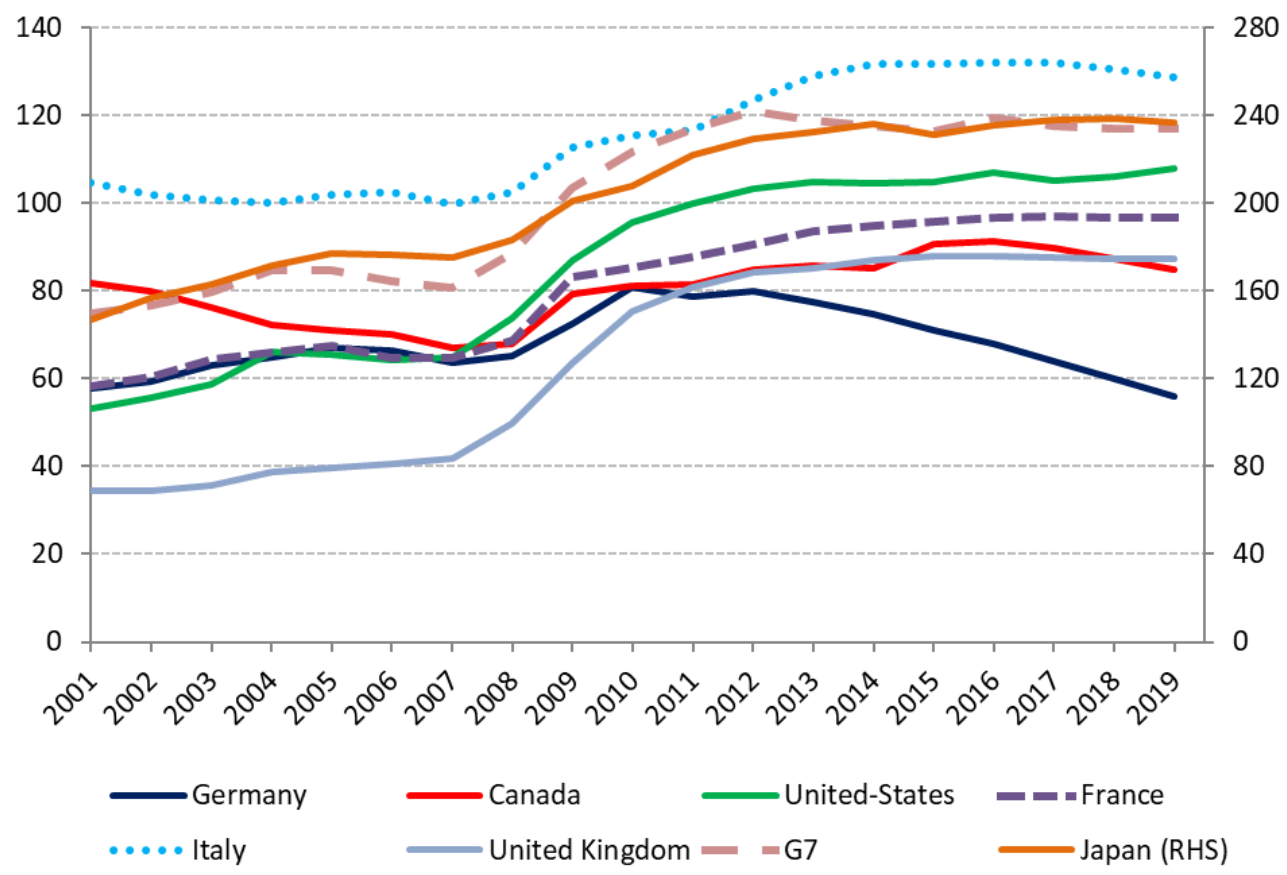

Sources: Datastream and IMF-WEO-general governmentgross debt 
Figure 2. G7 Central Banks' Balance Sheet (\% of GDP)

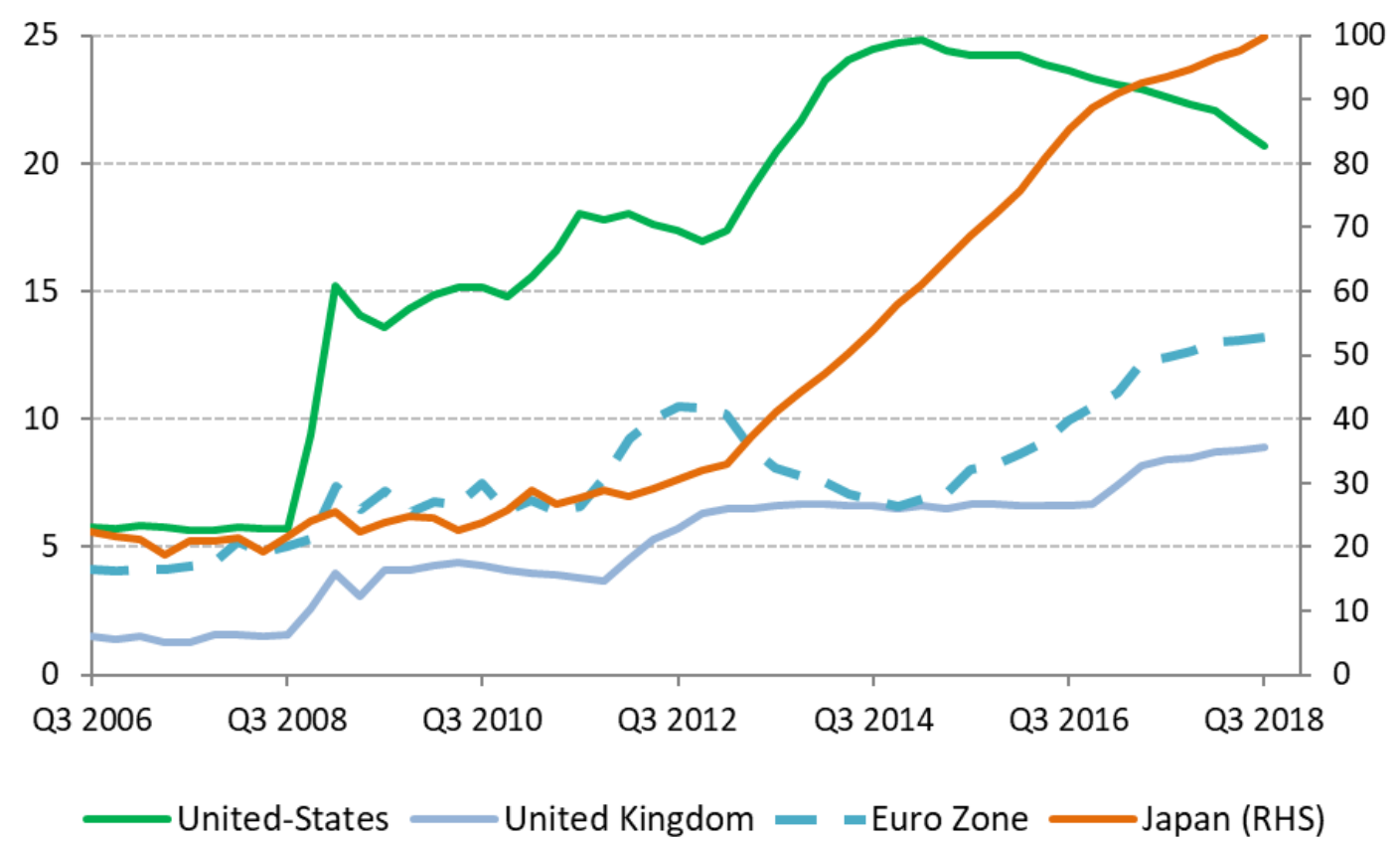

Sources: Datastream and national sources.

In this paper, we gauge the effects of higher debt levels, quantitative easing and lower interest rates by estimating pre- and-post global financial crisis (GFC) policy multipliers in the case of the U.S. The aim is to determine whether the expenditure and tax multipliers for the U.S. have fallen since the start of the GFC in late 2007.

The empirical approach draws on Blanchard and Perotti (2002). We first estimate the dynamic effects of debt-financed shocks in government spending and taxes, using the standard Blanchard and Perotti model involving per capita government expenditure, taxation and real gross domestic product. We find evidence that the fiscal multipliers have fallen after the start of the crisis. Note that Blanchard and Perotti (2002) abstract from government debt dynamics and monetary policy.

To better understand the reasons for the change in the fiscal multipliers relative to the precrisis levels, we augment the Blanchard and Perotti model to allow for the dynamic effects of shocks in the central bank's balance sheet, real interest rates and debt levels on economic activity. Given the elevated debt levels and significantly larger balance sheet, how large do fiscal and monetary policy measures need to be to deliver the desired support to the real economy? 
As in Blanchard and Perotti (2002), this paper uses a mixed structural VAR/event study approach. Identification relies on institutional information about the tax and transfer systems, central bank communication about their quantitative easing $(\mathrm{QE})$ and normalization process, and debt trajectory to infer the impact of policy shocks.

The empirical results show (positive) government spending shocks as having a positive effect on output, and (positive) tax shocks as having a negative effect. The estimated multipliers for spending and taxation shocks using the enhanced model have declined since the 2008 global financial crisis. This decline can in part be attributed to the increased debt burden accumulated since the GFC. Our paper offers two complementary angles: an interest rate angle, which in the short-run, given the substantial decline in real interest rates since the end of 2007, has probably acted to increase the fiscal multiplier, and a debt angle, which is likely to create a negative drag on real growth and hence the multiplier. Despite the presumption that policy multipliers are likely to increase in a low interest rate environment, this view is not supported in our model given the negative role played by large debt accumulation both in the short and the long run. There is also a risk that interest rates may not remain low for an extended period of time.

Many papers ${ }^{1}$, both theoretical and empirical, provide evidence that debt has a negative impact on the macro economy in the long run, especially when the debt to GDP ratio exceeds a threshold. The main channels that explain this relationship include private saving (via the impact of taxes to finance the interest payments on the debt on households' consumption and saving behavior), public investment (via the debt overhang), total factor productivity (via incentives for work and the use of capital and labor) and long-term interest rates (via crowding out of private investment).

The analysis also suggests that quantitative easing has a relatively small effect on the real economy compared to fiscal measures, and that future quantitative easing will need to be substantial to achieve a given policy target.

\section{MODEL}

The reduced-form VAR specification used for the analysis is:

$$
Y_{t}=\mu+\sum_{j=1}^{p} A_{j} Y_{t-j}+U_{t}
$$

in which

\footnotetext{
${ }^{1}$ See Checherita and Rother (2010) and literature review therein.
} 
$Y_{t}=\left[T_{t}, G_{t}, X_{t}\right]^{\prime}$ is a three-dimensional vector in the logarithms of quarterly taxes, primary expenditure and GDP, all measured in real, per capita terms.

$U_{t}=\left[t_{t}, g_{t}, x_{t}\right]^{\prime}$ is the vector of reduced-form residuals, which in general will have non-zero covariance terms (i.e., cross-correlations).

The reduced-form residuals have little economic significance as they are linear combinations of the "structural" or fundamental shocks of the corresponding structural VAR described below.

The $(3 \times 3) A_{j}$ matrices (of which there are $\left.p\right)$ contain the coefficients on the lagged dependent variables.

We use quarterly data to estimate the VAR. This is essential for identification of the fiscal shocks as explained in Blanchard and Perotti (see also below).

The corresponding structural VAR (SVAR) can be written as $\Omega U_{t}=\Phi V_{t}$ or

$$
\Omega Y_{t}=\mu^{\prime}+\sum_{j=1}^{p} A_{j}^{\prime} Y_{t-j}+\Phi V_{t}
$$

with structural shocks $V_{t}=\left[e_{t}^{t}, e_{t}^{g}, e_{t}^{x}\right]^{\prime}$, general matrices of structural coefficients given by

$$
\Omega=\left(\begin{array}{ccc}
1 & -a_{2} & -a_{3} \\
-b_{1} & 1 & -b_{3} \\
-c_{1} & -c_{2} & 1
\end{array}\right) \text { and } \Phi=\left(\begin{array}{ccc}
a_{4} & a_{5} & a_{6} \\
b_{4} & b_{5} & b_{6} \\
c_{4} & c_{5} & c_{6}
\end{array}\right)
$$

and

$$
\begin{gathered}
\mu^{\prime}=\Omega^{-1} \mu, \\
A_{j}^{\prime}=\Omega^{-1} A_{j}, j=1 \ldots p
\end{gathered}
$$

Note that the variance-covariance matrix of the VAR is $\Omega^{-1} \Phi\left(\Omega^{-1} \Phi\right)^{\prime}$.

The $\Omega$ matrix reflects the time $t$ relationships amongst the variables in $Y_{t}$, and $\Phi$ does the same for the structural shocks. There are $n 1$ 's along the diagonal of $\Omega$, each representing the dependent variable of a structural equation. The diagonal elements of $\Phi$ represent the standard errors of the structural shocks, while its off-diagonal elements are the (square root) of their covariance terms.

As is well-known, the fundamental problem in SVAR analysis is to estimate the unknown parameters in $\Omega$ and $\Phi$ from the ( $n \times n)$ variance-covariance matrix of the reduced-form model (i.e. the VAR). Because of its symmetry, this variance-covariance matrix has $\frac{n(n+1)}{2}$ unique values that can be used to determine up to the same number of distinct parameters in 
both $\Omega$ and $\Phi$ combined. The above system requires plausible restrictions to achieve exact identification.

For example, if $\Phi$ is diagonal, there will be a total of ( $n \times n)$ parameters to estimate in both $\Omega$ and $\Phi$ combined. In this case, $\left(n^{2}-\frac{n(n+1)}{2}\right)=\frac{n(n-1)}{2}$ is the number of restrictions that needs to be imposed to exactly identify the SVAR. Since $\Phi$ in general may not be diagonal (e.g., as in Blanchard and Perotti), it is best to use the maximum number of parameters that a VAR can estimate to dictate whether the model is identified. This number needs to be compared to the number of unknowns in both $\Omega$ and $\Phi$ combined. If the number of unknowns exceeds the number of knowns, the SVAR is said to be unidentified and extra restrictions are required before estimation can proceed. If there is an exact match, the model is said to be exactly identified, and an estimation becomes feasible. When the number of unknowns is less than the number of parameters that the VAR can estimate (i.e., $\left.\frac{n(n+1)}{2}\right)$, the model is said to be over-identified. The validity of the over-identifying restrictions can be tested using a standard $\chi^{2}$ criterion.

In the Blanchard-Perotti model, $n=3$, and hence we can estimate a maximum of 6 parameters. We suggest the following identification restrictions for the model:

$$
\Omega=\left(\begin{array}{ccc}
1 & 0 & -2.08 \\
0 & 1 & 0 \\
-c_{1} & -c_{2} & 1
\end{array}\right) \text { and } \Phi=\left(\begin{array}{ccc}
a_{4} & a_{5} & 0 \\
b_{4} & b_{5} & 0 \\
0 & 0 & c_{6}
\end{array}\right)
$$

Note that the matrix $\Omega$ corresponds exactly to the identifying assumptions used in Blanchard and Perotti (2002) to estimate the fiscal multiplier. A similar correspondence applies to the matrix $\Phi$.

The model is under-identified as presented, as there are seven unknown parameters in $\Omega$ and $\Phi$ combined - one more than can be estimated from the reduced-form model. In the Blanchard and Perotti (2002) case, either $a_{5}$ or $b_{4}$ is alternatively set to zero to achieve exact identification.

The first row of the matrix models the evolution of taxes and can be interpreted as follows: unexpected movements in taxes within a quarter, $t$, can be driven separately by three factors: the response of taxes to unexpected movements in GDP, $a_{3} x_{t}$, with $a_{3}=2.08$, the response to structural shocks to taxes, $a_{4} e_{t}^{t}$, and the response to structural shocks to spending, $a_{5} e_{t}^{g}$. A similar interpretation applies to unexpected movements in expenditure in the second row. The $3^{\text {rd }}$ row implies that unexpected movements in output can be attributed to unexpected movements in taxes, spending or to an unexpected shock to output, $e_{t}^{x}$.

We now present more detailed explanations regarding the identification of this system. As in Blanchard and Perotti (2002), we rely on institutional information about tax, transfer and spending programs to constrain the parameters $a_{3}$ and $b_{3}$. In general, these coefficients 
capture two different effects of activity on taxes and spending: the automatic effects of economic activity on tax es and spending under existing fiscal policy rules, and any discretionary adjustment made to fiscal policy in response to unexpected events within the quarter. The key to Blanchard and Perotti's approach to identification is to recognize that the use of quarterly data virtually eliminates the second channel (i.e., $b_{3}=0$ ). They cite direct evidence on the conduct of fiscal policy that suggests that it takes policymakers and legislatures more than a quarter to learn about a GDP shock, decide what fiscal measures to take in response, pass these measures through the legislature, and implement them. ${ }^{2}$ The estimate of the elasticity of taxes to a shock in output, after allowing for cyclical effects, is 2.08 (for quarterly data). We take this value as a starting point and assess below the sensitivity of our estimates of the fiscal multiplier to reasonable deviations of $a_{3}$ from 2.08 .

\section{RESULTS : STANDARD BLANCHARD-PEROTTI APPLIED TO THE U.S., PRE- AND POST-GFC}

Figure 3 (Panel A) depicts the behaviour of real GDP, real primary expenditure and real taxes per capita during 1966Q1-2019Q4. Panel B shows their respective growth rates during 2005Q1-2019Q4. The severity of the 2007 global crisis on the U.S. economy is demonstrated by Panels A and B. The negative growth in real GDP per capita in 2008-09 was associated with significant (largely endogneous) declines in taxes per capita and substantial increases in government expenditure, together implying larger primary deficits and a higher debt-to-GDP ratio after 2007 (see Figure 1).

As noted in the U.S. Article IV consultation in 2008, fiscal stimulus was then providing welltimed support to activity, more than offsetting short-term strains on income and borrowing. The stimulus package of over 1 percent of GDP mainly comprised tax rebates targeted at low- and middle-income individuals. This targeting helped offset the fact that temporary stimulus tends to generate a smaller boost to demand than a permanent change.

We computed the impulse responses of real GDP per capita to a given deficit-financed shock to expenditure, which is the expenditure multiplier, pre- and post-crisis. We use a one-dollar (unit) shock in expenditure in this case (rather than, say, the standard deviation of the structural shock during the estimation period) to ensure that the impulse-response functions pre- and post-crisis (i.e. the multipliers) can be compared directly. We also computed the impulse response of real GDP per capita to a unit shock to taxes to obtain the tax multiplier. ${ }^{3}$

In Figure 4, the blue curves are the expenditure and tax multipliers from the BlanchardPerotti model estimated with data to $2007 \mathrm{Q} 4$, while the orange curves are the same

\footnotetext{
${ }^{2}$ We investiga te therole of this restriction in the expanded model in section IV.

${ }^{3}$ The shocks are one-period shocks. Multi-period shocks or a combination of policy shocks can a lso be introduced but imply a different, more complex, policy experiment. Moreover, the resulting impulse response functions would notbe consistent with the traditional definition of a multiplier.
} 
multipliers estimated using data up to 2019Q4. The multipliers confirm that the pre-crisis responses are stronger than the post-crises responses.

For the U.S., after eight quarters, the impulse response to an expenditure shock is larger (actually more than four times larger) using the model estimated up to 2007 than the same model estimated using data that extends to 2019. This suggests that the expenditure multiplier has fallen since the GFC. In addition, after eight quarters, the impulse response to a tax shock is more negative (almost 40 percent larger in absolute terms) for the shorter estimation period (i.e., prior to the GFC) than the impulse response from the model estimated using data up to 2019. This suggests that the U.S. tax mulitplier has also fallen in absolute terms since the onset of the GFC.

\section{Figure 3. U.S. Real GDP, Primary Expenditure and Taxation (per capita),} 2005Q1-2019Q4

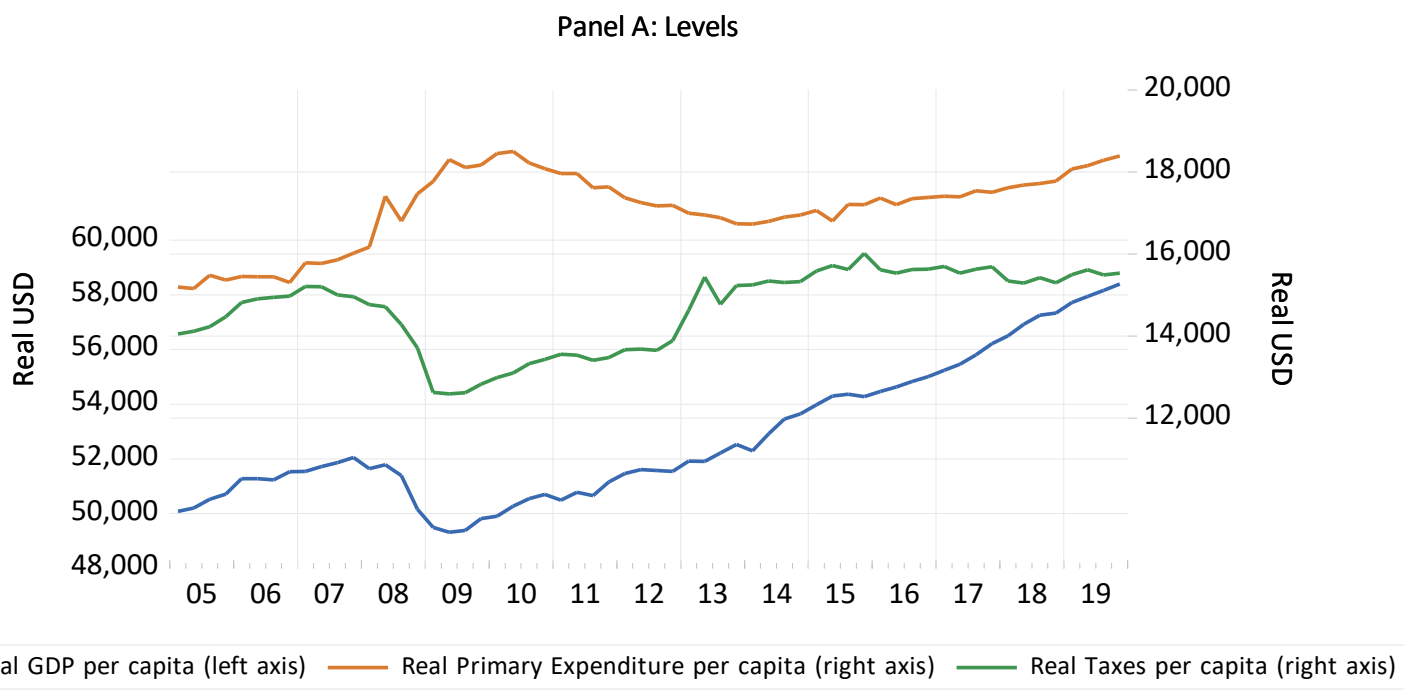

Panel B: Growth Rate

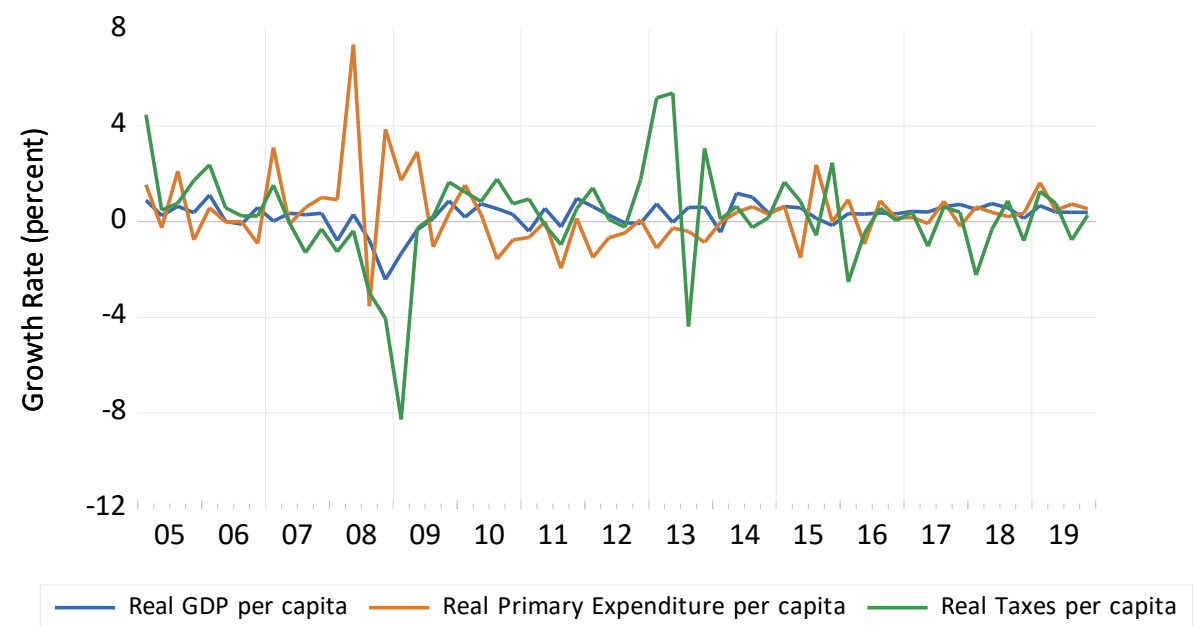


Figure 4. Policy Multipliers for the U.S.

Expenditure Multiplier (Unit Shock, \$), Pre-and Post-Crisis: USA

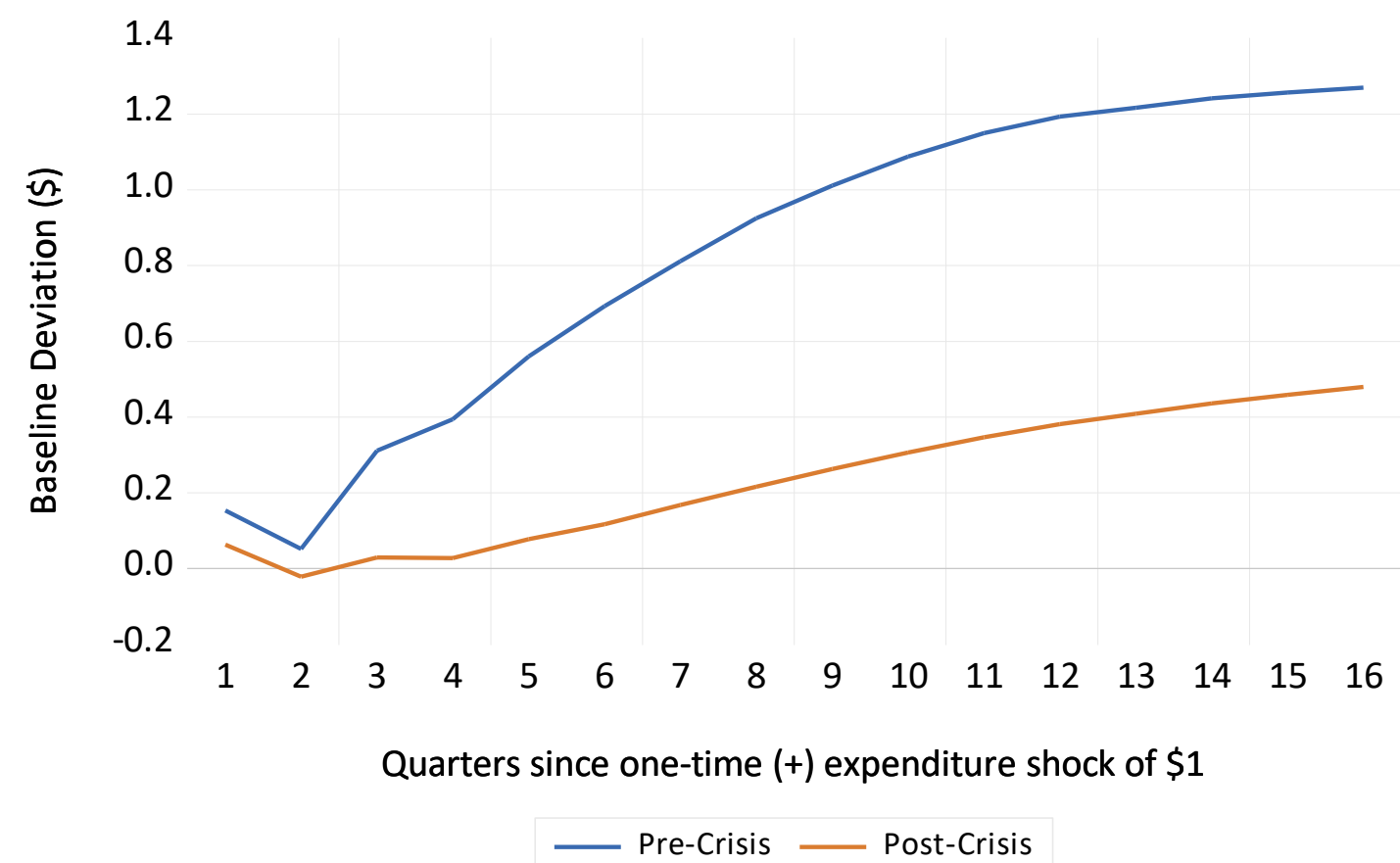

Tax Multiplier (Unit Shock, \$), Pre-and Post-Crisis: USA

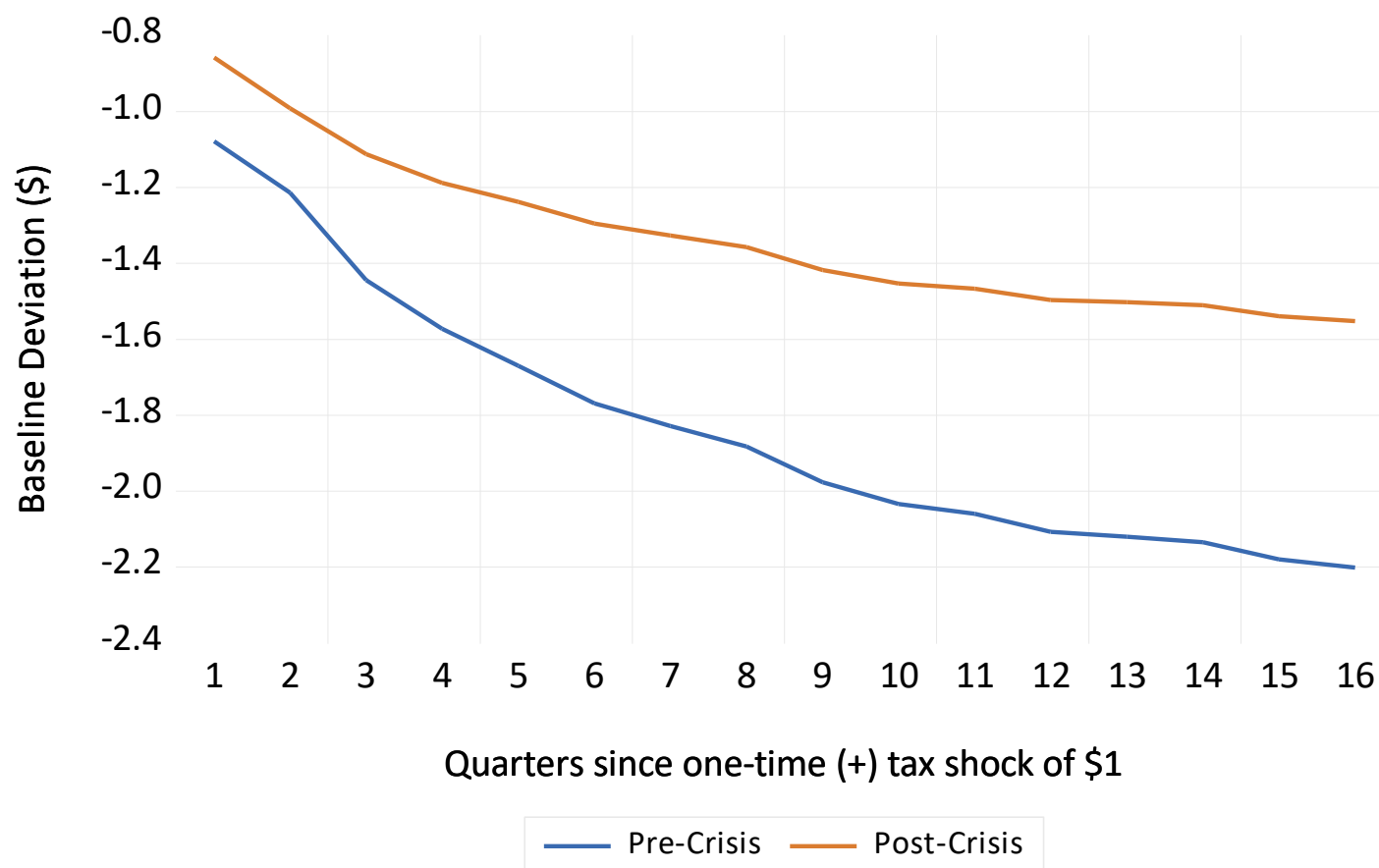

(CInternational Monetary Fund. Not for Redistribution 


\section{EXPANDED MODEL}

The strength of fiscal policy in the U.S. appears to have weakened post-GFC using the standard Blanchard-Perotti model (Figure 4). To understand the reasons behind the change in the multipliers and to guard against omitted variable bias, we now enhance the analysis by adding key macroeconomic variables in the standard model - namely the size of the central bank balance sheet ${ }^{4}$, the real interest rate and the debt-to-GDP ratio - to assess better the change in the multipliers pre- and post-crisis. ${ }^{5}$

The reduced-form VAR specification used for this analysis is:

$$
Y_{t}=\mu+\sum_{j=1}^{p} A_{j} Y_{t-j}+\sum_{i=0}^{k} C_{i} D_{t-i}+U_{t}
$$

where $Y_{t}=\left[T_{t}, G_{t}, X_{t}, B S_{t}, R_{t}\right]^{\prime}$ is a five-dimensional vector in the logarithms of quarterly taxes, primary spending, GDP (all measured in real, per capita terms), the central bank balance sheet size relative to GDP and the real interest rate. $D_{t}$ is the debt-to-GDP ratio. It is given a separate role in the VAR as it satisfies the following non-linear identity:

$$
D_{t}=\frac{\left(1+R_{t}\right)}{\left(1+\Delta X_{t}\right)} D_{t-1}+P B_{t}
$$

where $\Delta X_{t}$ is the real growth rate in GDP and $P B_{t}$ denotes the primary balance. Note that $D_{t}$ does not depend on any unknown parameters and hence it can be treated as an exogenous variable for estimation purposes. We allow current and lagged values of $D_{t}$ to enter the VAR, although not necessarily in each equation.

$U_{t}=\left[t_{t}, g_{t}, x_{t}, b s_{t}, r_{t}\right]^{\prime}$ is the vector of reduced-form residuals, which in general will have non-zero covariance terms (i.e., cross-correlations). The reduced-form residuals have little economic significance as they are linear combinations of the "structural" or fundamental shocks of the corresponding structural VAR described below.

\footnotetext{
${ }^{4}$ The Fed's ba lance sheet movements could be a proxy for the stock market. A plausible driver of equity prices may have been increased liquidity arising from monetary policy choices by the Fed, which took the form of siza ble a sset purchases (and hence balance sheet changes) together with interest rate reductions.

${ }^{5}$ Other factors may contribute to the impact of a fiscal shock on output, including the persistence of the change, whether the shock wa s anticipated or not, how monetary policy reacts, a nd other characteristics of the economy such as the exchange ra te regime. See Ramey (2019). Our model does not takesuch features into account.
} 
The ( $5 \times 5) A_{j}$ matrices (of which there are $p$ ) contain the coefficients on the lagged dependent variables, and the $(5 \times 1) C_{j}$ vector (of which there are $\left.(k+1)\right)$ contain the coefficients on the debt-to-GDP ratio. As mentioned previously, some of the elements of $A_{j}$ and $C_{j}$ may be constrained to zero to prevent the debt-to-GDP ratio to affect a specific element of $Y_{t}$, either contemporaneously or with a lag.

As before, we use quarterly data to estimate the VAR. The corresponding structural VAR (SVAR) can be written as

$$
\Omega U_{t}=\Phi V_{t}
$$

or

$$
\Omega Y_{t}=\mu^{\prime}+\sum_{j=1}^{p} A_{j}^{\prime} Y_{t-j}+\sum_{i=0}^{k} C_{i}^{\prime} D_{t-i}+\Phi V_{t}
$$

with structural shocks $V_{t}=\left[e_{t}^{t}, e_{t}^{g}, e_{t}^{x}, e_{t}^{b s}, e_{t}^{r}\right]^{\prime}$, matrices of coefficients denoted

$$
\Omega=\left(\begin{array}{ccccc}
1 & -a_{2} & -a_{3} & -a_{4} & -a_{5} \\
-b_{1} & 1 & -b_{3} & -b_{4} & -b_{5} \\
-c_{1} & -c_{2} & 1 & -c_{4} & -c_{5} \\
-k_{1} & -k_{2} & -k_{3} & 1 & -k_{5} \\
-l_{1} & -l_{2} & -l_{3} & -l_{4} & 1
\end{array}\right) \text { and } \Phi=\left(\begin{array}{ccccc}
a_{6} & a_{7} & a_{8} & a_{9} & a_{10} \\
b_{6} & b_{7} & b_{8} & b_{9} & b_{10} \\
c_{6} & c_{7} & c_{8} & c_{9} & c_{10} \\
k_{6} & k_{7} & k_{8} & k_{9} & k_{10} \\
l_{6} & l_{7} & l_{8} & l_{9} & l_{10}
\end{array}\right)
$$

and

$$
\begin{gathered}
\mu^{\prime}=\Omega^{-1} \mu, \\
A_{j}^{\prime}=\Omega^{-1} A_{j}, j=1, \ldots, p \\
C_{i}^{\prime}=\Omega^{-1} C_{i}, i=0, \ldots, k
\end{gathered}
$$

Recall that the variance-covariance matrix has $\frac{n(n+1)}{2}$ unique values that can be used to determine up to the same number of distinct parameters in both $\Omega$ and $\Phi$ combined.

It follows that we can now estimate a maximum of 15 parameters since there are $n=5$ endogenous variables in the expanded model. We suggest the following identification restrictions for the augmented model: 


$$
\Omega=\left(\begin{array}{ccccc}
1 & -a_{2} & -2.08 & 0 & -a_{5} \\
-b_{1} & 1 & 0 & 0 & -b_{5} \\
-c_{1} & -c_{2} & 1 & -c_{4} & -c_{5} \\
0 & 0 & -k_{3} & 1 & 0 \\
0 & 0 & -l_{3} & 0 & 1
\end{array}\right) \text { and } \Phi=\left(\begin{array}{ccccc}
a_{6} & 0 & 0 & 0 & 0 \\
0 & b_{7} & 0 & 0 & 0 \\
0 & 0 & c_{8} & 0 & 0 \\
0 & 0 & 0 & k_{9} & 0 \\
0 & 0 & 0 & 0 & l_{10}
\end{array}\right)
$$

The first row of the matrix models the evolution of taxes and can be interpreted as follows: unexpected movements in taxes within a quarter, $t$, can be driven separately by four factors: the response of taxes to unexpected movements in expenditure, $a_{2} g_{t}$, the response of taxes to unexpected movements in GDP, $a_{3} x_{t}$, with $a_{3}=2.08$, the response to unexpected movements in the real interest rate, namely $a_{5} r_{t}$, and the response to structural shocks to taxes, $a_{6} e_{t}^{t}$. A similar interpretation applies to unexpected movements in spending in the second row, the balance sheet in row 4 and the interest rate in row 5 . The $3^{\text {rd }}$ row states that unexpected movements in output can be attributed to unexpected movements in taxes, spending, the balance sheet or interest rate, or to an unexpected structural shock to output, $e_{t}^{x}$.

The chosen identification in the above matrices is richer than that of Blanchard-Perotti (2002) to the extent that taxes respond to expenditure (via $a_{2}$ ) and expenditure responds to taxes (via $b_{1}$ ) within the same model. In Blanchard-Perotti (2002), one model allows taxes to respond to structural shocks to spending, $a_{5} e_{t}^{g}$, while another model allows expenditure to respond to structural shocks to taxes, $b_{4} e_{t}^{t}$, and they do not allow for direct and simultaneous responses of taxes to expenditure, and expenditure to taxes, as they set $a_{2}$ and $b_{1}$ equal to $0 .{ }^{6}$ In contrast, our model displays exact identification without arbitrary assumptions.

Given the more detailed explanations about the identification of this system presented earlier, we first assume $b_{3}=0$ (following Blanchard and Perotti (2002)). We set the estimate of the elasticity of taxes to a shock in output, $a_{3}$, after allowing for cyclical effects, to 2.08 (for quarterly data). We take these values as a starting point and a) assess below the sensitivity of our estimates of the fiscal multiplier to reasonable deviations of $a_{3}$ from 2.08; and $\mathrm{b}$ ) the impact of relaxing $b_{3}=0$ and setting either $a_{5}=0$ or $b_{5}=0$.

The identification chosen assumes that only the structural shocks of a given variable impact on that variable, hence a diagonal $\Phi$ matrix (i.e. structural shocks are uncorrelated). ${ }^{7}$ In addition, we assumed that unexpected movements in the balance sheet or the interest rate are not subject to movements in taxes and expenditure, but only to their respective structural shocks and to output movements. Finally, we assumed that unexpected movements in taxes and expenditure are not subject to movements in the balance sheet.

\footnotetext{
${ }^{6}$ See the ma trix representation in Section II.

${ }^{7}$ Fully identified SVARs a re simultaneous equation systems that deal with endogeneity via the specific identification constraints imposed. A core identifying a ssumption of our approach is that the errors of the SVAR a re uncorrelated. Hence there is no endogeneity bias given our identification a ssumptions.
} 
For the purpose of estimation, we assume that changes in the debt-to-GDP ratio affect only GDP per capita (i.e., $x_{t}$ ) contemporaneously. Thus, the $3^{\text {rd }}$ element of $C_{0}^{\prime}$ is non-zero and all other variables in $Y_{t}$ are assumed to be invariant to contemporaneous shocks in the debt-toGDP ratio. We allow lagged values of the debt-to-GDP ratio to affect expenditure, taxes, and real GDP per capita.

\section{DATA AND ESTIMATION APPROACH}

The enhanced framework contains three additional variables compared to the BlanchardPerotti model: central bank balance sheet asset holdings relative to GDP, the real interest rate and the debt-to-GDP ratio. These variables represent the monetary sector in that they reflect the manner in which the U.S. government has financed its deficit (typically by borrowing), the extent of quantitative easing in the form of asset acquisition by the Federal Reserve and the state of monetary policy (i.e., the nominal and hence real interest rate).

We estimated the model using U.S. quarterly data for 1966Q1-2019Q4. The central bank assets are the Federal Reserve's asset holdings as at the end of each quarter. The real interest rate is the 10-year bond yield less the inflation rate, the latter measured using the GDP deflator. The debt-to-GDP ratio is the outstanding debt of the general government (federal and state) divided by nominal GDP.

The growth rate of the three series are shown separately in Figure 5 against the growth rate in real GDP per capita (Panels A to C). The variables changed significantly after the start of the financial crisis in 2007, especially government debt accumulation and asset purchases by the Federal Reserve. In terms of levels (not shown), the debt ratio increased from 63 percent at the end of 2007 to approximately 107 percent by the end of 2019, while Federal Reserve asset holdings increased from 6 to 19 percent of GDP over the same period. ${ }^{8}$

Our prior is that these significant movements have had a lasting negative effect on the strength of key policy multipliers. The result of our analysis supports this view. To estimate the SVAR, we first estimated an unconstrained VAR in levels with a single lag of the 5 endogenous variables (i.e., real revenue per capita, real expenditure per capita, real GDP per capita, Federal Reserve balance sheet assets, and the real interest rate), and the debt-to-GDP ratio as an exogenous variable. The lag length was chosen using the Schwarz Information Criterion.

As the variables were confirmed to possess unit roots using standard unit root procedures, we also tested for cointegration and detected a single cointegrating vector. As such, the appropriate model to estimate is a structural vector error correction model (SVECM).

We estimated this SVECM using the method introduced in Pagan and Pesaran (2008). It involves rewriting the SVAR in terms of a subset of the endogenous variables and all of the

\footnotetext{
${ }^{8}$ The FederalReserve asset ra tio relative to GDP peaked at 25 percent at the end of 2014 (see Figure 2).
} 
residuals of the cointegrating vectors (i.e. the error correction terms), which are required to be transitory shocks according to their methodology. Given that there is a single cointegrating vector in our model, we setup the SVAR so that it has four (rather than five) structural shocks with permanent effects (which we assumed to be $e_{t}^{t}, e_{t}^{g}, e_{t}^{x}, e_{t}^{r}$ ), and one transitory shock. Doing so is equivalent to imposing a long-run restriction on the SVAR that the error-correction term does not have a permanent effect on the other variables. The SVECM, which remains exactly identified with these long-run constraints imposed, is nonlinear by construction, and estimation was carried out using the method of maximum likelihood.

Figure 5. Asset Holdings, Debt-to-GDP and the Real Interest Rate
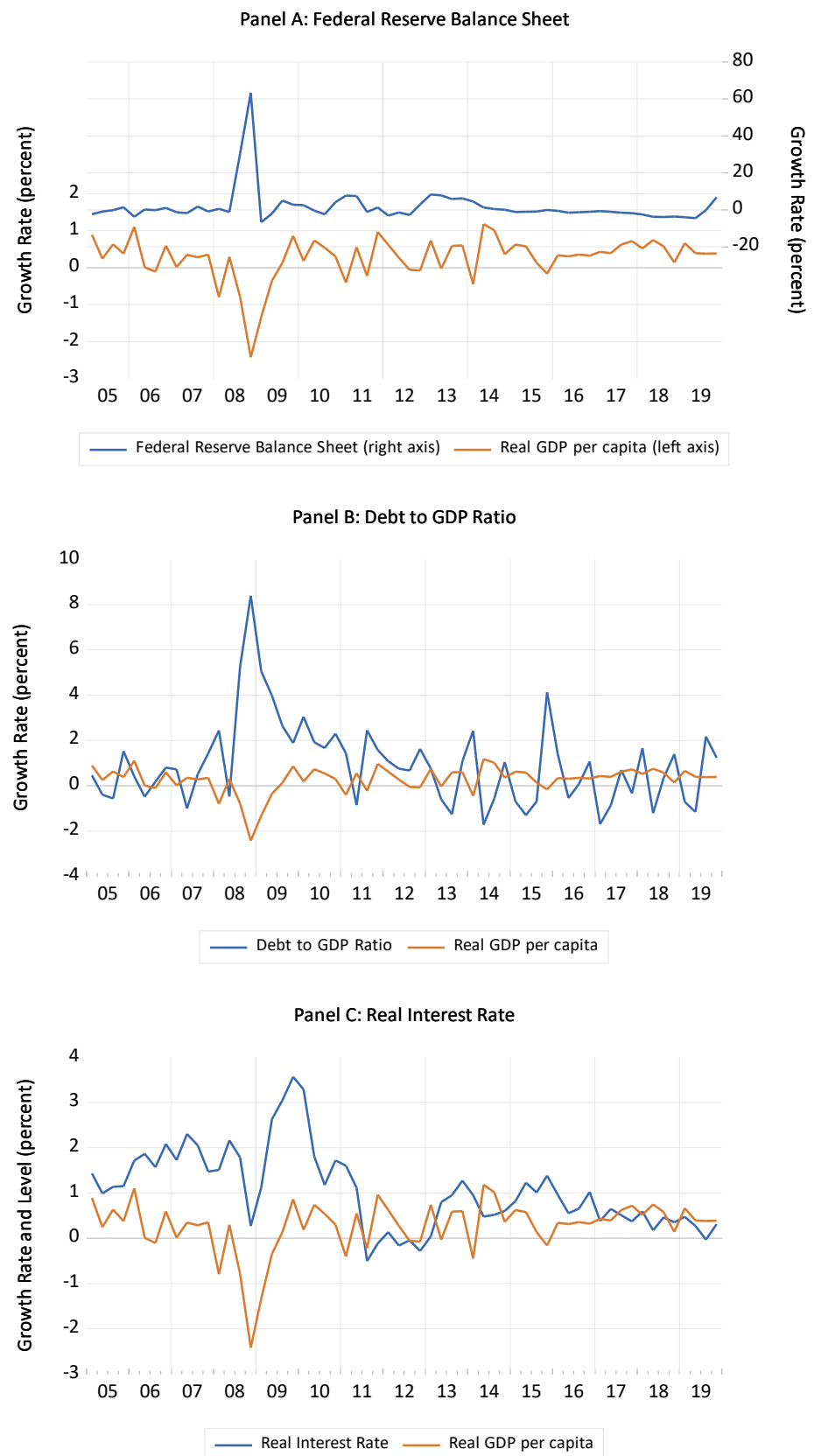


\section{RESULTS: MULTIPLIERS PRE- AND POST-GFC}

We now consider various policy adjustment scenarios and discuss the response of real GDP per capita to these shocks. For each shock, we use 2 datasets to measure the sensitivity of real-per capita GDP: (a) the SVECM estimated with the full sample (i.e., 1966Q1 to 2019Q4) and (b) the same model estimated with pre-crisis data (1966Q1-2007Q4). ${ }^{9}$ The objective is to assess whether there has been a change in the corresponding multipliers since the crisis, and thus to draw conclusions on the efficacy of macro policy choices pre- and post-crisis. We also compare the pre- and post-behavior of real GDP following a shock to the debt ratio. We assume without loss of generality that the shock occurs in 2006Q1 for the pre-crisis model and in 2018Q1 for the post-crisis model, and we trace the response of real GDP per capita for 8 quarters after the shock. Although the initial shocks are separated by 12 years (48 quarters) and hence different value wise, the responses of GDP per capita are comparable because in both cases the shock is a unit percentage change, and we express the corresponding response in real GDP per capita as the percentage change relative to the baseline. ${ }^{10}$

The first scenario involves a percentage point increase in the debt ratio. Figure 6 shows the percentage change in real GDP per capita relative to the baseline for the post-crisis and precrisis periods. Following the positive shock to the debt ratio, real GDP decreases initially both pre- and post-crisis, with the negative effect being slightly larger pre-crisis (Panel A). After 4 periods, the impact of higher debt on real GDP is still negative but declining toward zero, though the negative impact is larger post-crisis compared to pre-crisis in absolute terms. The large initial negative impact may be due to negative expectations, including expectations of higher taxes, arising from higher debt. The overall (ie., accumulated) impact of higher

\footnotetext{
${ }^{9}$ Another approach might be to estimate them odels over separate samples and compare the corresponding multipliers obtained. We could not use th is approach because there are too many unknown parameters in the model rela tive to thenumber of observations post GFC (i.e., 2008Q1-2019Q4).

${ }^{10}$ The percentage response in realGDP per ca pita to a onepercent change in real expenditure, for example, can be converted to dollar terms by scaling the impulse responses by $(1 / x)$, where $x$ is expenditure expressed a s a proportion of realGDP per ca pita. The a verage shares(i.e., conversion factors) for the two periods are:
}

\begin{tabular}{|c|c|c|c|c|}
\hline Variable & $\begin{array}{c}\text { Average Shares } \\
\text { 2004Q1-2007Q4 }\end{array}$ & $\begin{array}{c}\text { Conversion Factor } \\
\text { 2004Q1-2007Q4 }\end{array}$ & $\begin{array}{c}\text { Average Shares } \\
\text { 2016Q1-2019Q4 }\end{array}$ & $\begin{array}{c}\text { Conversion Factor } \\
\text { 2016Q1-2019Q4 }\end{array}$ \\
\hline $\begin{array}{c}\text { RealPrimary } \\
\text { Expenditure per capita }\end{array}$ & 0.30 & 3.3 & 0.31 & 3.2 \\
\hline RealTaxes & 0.28 & 3.6 & 0.28 & 3.6 \\
\hline $\begin{array}{c}\text { FederalReserve Asset } \\
\text { holdings relative to } \\
\text { GDP }\end{array}$ & 0.06 & 16.6 & 0.23 & 4.4 \\
\hline
\end{tabular}

The conversion factors are sensitive to the sample period, and for this rea son, themultipliers are expressed in ela sticity terms in the paper. See Ramey (2019) for further discussion on this point. 
government debt on real GDP is negative (Panel B), a result that is consistent with a large number of studies. ${ }^{11}$ Both theoretical and empirical papers provide evidence that debt has a negative impact on the macro economy in the long run, especially when the debt to GDP ratio exceeds a threshold. The main channels that explain this relationship include private saving (via the impact of taxes to finance the interest payments on the debt on households' consumption and saving behavior), public investment (via the debt overhang), total factor productivity (via incentives for work, and the use of capital and labor) and long-term interest rates (via crowding out of private investment). We do not believe that the negative relationship between debt and growth is based on solvency concerns for the U.S., but the U.S. debt level, which reached 107 percent by March 2020, may be approaching or reached levels where debt has a negative effect on real growth.

Figure 6. Impact of Higher Debt on Real GDP per capita

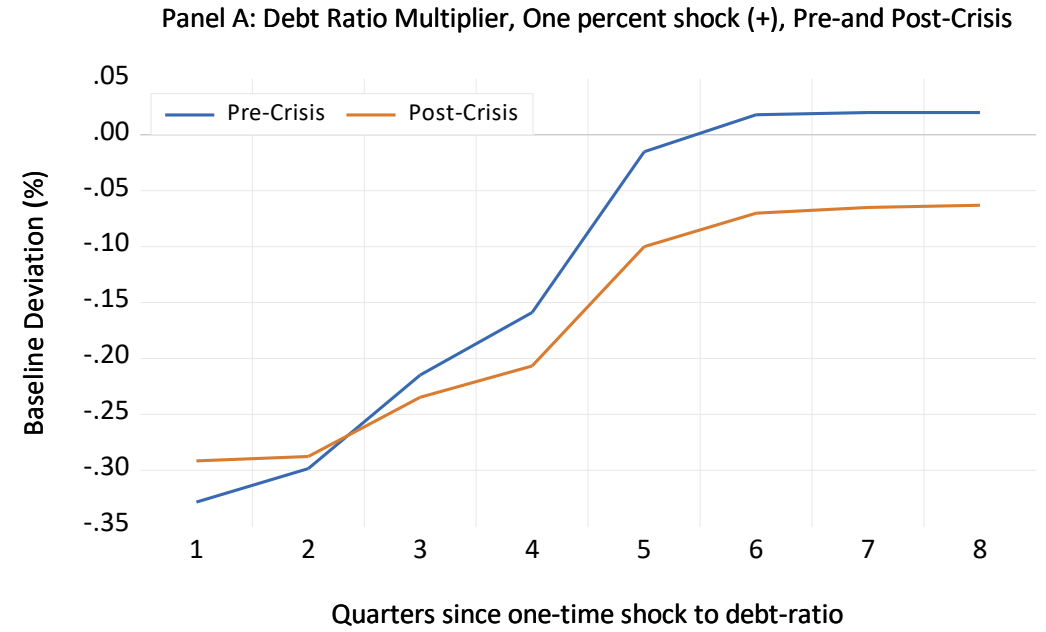

Panel B: Debt Ratio Multiplier, Accumulated, One percent shock (+), Pre-and Post-Crisis

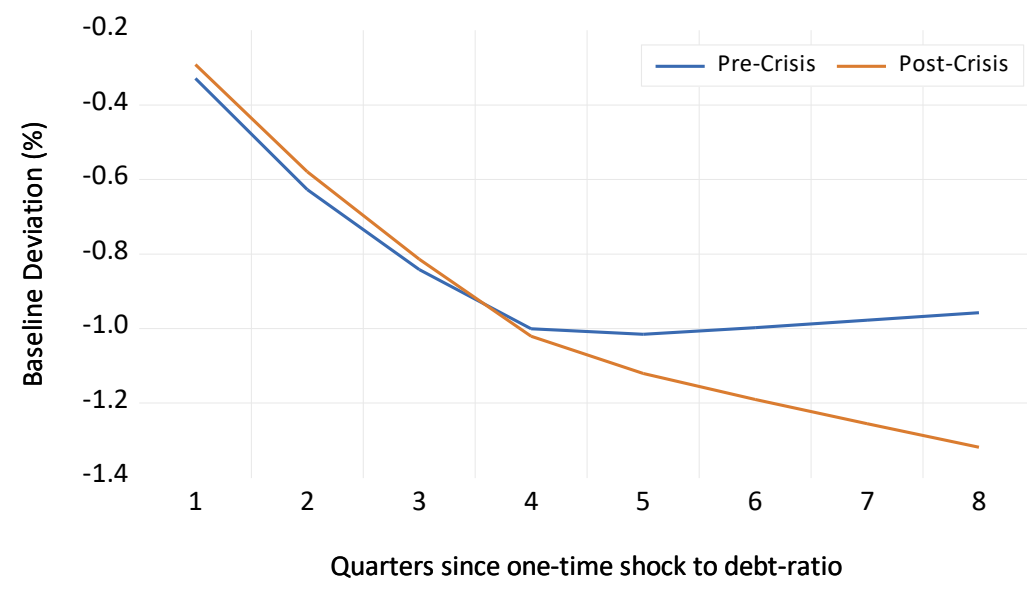

${ }^{11}$ de Rugy and Sa lmon (2020). 
The second scenario involves a percentage point increase in government expenditure (deficitfinanced). Figure 7A shows the percentage change in real GDP per capita relative to the baseline (i.e., the fiscal multiplier expressed in elasticity terms) for the post-crisis and precrisis periods. Note that following the shock in expenditure, both multipliers display a consistent positive response in terms of real GDP per capita. However, the fiscal multiplier has clearly declined post 2008Q1, suggesting that the efficacy of fiscal expenditure shocks has fallen. The parameter estimates suggest there has been a significant decline in the sensitivity of real GDP per capita to increases in government expenditure post-GFC, and a larger negative drag from increases in government debt. ${ }^{12}$ Given that the estimated coefficient on the debt ratio in the real GDP per capita equation is negative and larger (in absolute terms) using post-crisis data, the decline in the expenditure multiplier can in part be attributed to the larger negative feedback mechanism between an increase in expenditure and rises in government debt, contributing, other things being equal, to larger fiscal deficits, slower growth and debt accumulation in subsequent periods. In a low interest rate environment, debt accumulation may seem less of an issue, but this view is not supported here because of the larger negative estimated coefficient on the debt ratio. ${ }^{13}$

The third scenario involves a percentage point increase in government taxes. Figure 7B shows the change in real GDP per capita (i.e., the tax multiplier) relative to the baseline for the post-crisis and pre-crisis periods. Following the shock in taxes, both multipliers display a consistent negative response in terms of real GDP per capita. The estimated elasticity of taxes in the real GDP per capita equation has increased slightly (in absolute terms) postcrisis. This effect is offset somewhat by a reduction in the debt-ratio owing to the higher taxes. There is an uncertainty element regarding the transitory versus permanent nature of a tax policy, which impacts the consumption/saving behavior, and ultimately, real GDP. ${ }^{14}$

For the fourth scenario, we consider a one-time percentage point increase in the Federal Reserve's balance sheet relative to GDP that is not reversed in later periods. Figure 7C shows the change in real GDP per capita with respect to the baseline, for both the post-crisis and pre-crisis periods. Following the shock, both multipliers are positive though rather small, underscoring the need for sizable increases (e.g., 10 times) in the balance sheet to have the same effect on GDP per capita as, for example, an increase in primary expenditure. The impact of a shock to the Federal Reserve's balance sheet is estimated to be relatively weaker in the post-crisis years than the pre-crisis years. This result may be linked to the large amount of liquidity needed after the crisis, or said differently, the fact that there was no need for liquidity injection or an accommodative stance before the crisis. The results suggest that quantitative easing is beneficial, but requires sizable balance sheet interventions to lead to noticeable effects on GDP. The estimated coefficients on the balance sheet variable in the

\footnotetext{
${ }^{12}$ The parameter estimates on the government debt ra tio are statistically different pre-a and post-GFC.

${ }^{13}$ Our results provide further evidence of the negative rela tionship between debt-to-GDP and the expenditure multiplier. See Ramey (2019) a nd Iltzetzki, Mendoza and Végh (2013).

${ }^{14}$ These findings a re robust to the specific setting of the elasticity of GDP in the tax equation(i.e., 2.08). It can be shown that both the expenditure and Federal Reserve asset holding multipliers a re inversely rela ted to the value of the ela sticity of GDP in the tax equation.
} 
GDP equation are positive pre- and post-crisis, but the post-crisis coefficient is slightly lower. In turn, the estimated coefficients on output in the balance sheet equation are negative pre- and post-crisis, with the post-crisis coefficient three times lower. These results combined may explain the need for more quantitative easing post-crisis.

In the fifth scenario, we consider the response of real GDP per capita (in percentage terms) to a 100 basis points increase in the interest rate. Figure 7D shows the change in real GDP per capita relative to the baseline. The increase in interest rates has the expected negative impact on the economy pre- and post-GFC. The negative impact is initially weaker in the post-crisis years than the pre-crisis years in absolute terms. After the second period, the post-crisis impact is larger in absolute terms. This could be due to the higher government debt in the post-crisis period, which implies higher interest payments on the debt. Other things being equal, it also implies faster accumulation of debt, and given the larger post-crisis negative coefficient on the debt-ratio in the real GDP equation, a larger drag on real GDP from positive shocks to the real interest rate. This result is consistent with the debt multiplier in Figure 6, which suggests a delayed differential pre- and post-crisis response of GDP to a debt shock and debt accumulation. ${ }^{15}$

Table 1 presents F-statistics for the null-hypothesis that the impulse response functions (i.e. the multipliers) are the same pre- and post-GFC. The F-statistic for each impulse response function assesses whether the parameters of $\Omega, A_{1}^{\prime}$ and $C_{i}^{\prime}$ associated with the real GDP per capita equation in $\Omega Y_{t}=\mu^{\prime}+A_{1}^{\prime} Y_{t-1}+\sum_{i=0}^{k} C_{i}^{\prime} D_{t-i}+\Phi V_{t}$ have changed significantly preand post-GFC. ${ }^{16}$ The null hypothesis of no change is rejected convincingly for all the policy multipliers.

We now provide the corresponding historical decomposition of the SVECM, as defined in Burbridge and Harrison (1985). A historical decomposition uses the estimated impulse response functions of the SVECM to decompose the within-sample structural errors of the endogenous variables. The decomposition is derived by shocking the baseline using the estimated structural errors of each endogenous variable, including debt-to-GDP, thereby identifying the contribution of each structural error to the deviations from the baseline. The changes in the baseline are accumulated each quarter to obtain the cumulative response of real GDP per capita to a given structural error, yielding a measure of the importance of each historical (structural) shock to the movements in real GDP per capita relative to its baseline. The changes in the historical decomposition across the two sample periods reflect the differences in the size and importance of the structural errors during these periods and the changes in the estimated impulse response functions pre- and post-crisis.

\footnotetext{
${ }^{15} \mathrm{We}$ a lso estimated the SVECMusing two alternative identifying a ssumptions, namely $b_{3} \neq 0 ; a_{5}=0$ and $b_{3} \neq 0 ; b_{5}=0$. Both models relax the Bla nchard and Perotti (2003) assumption that government expenditure does not respond within one quarter to changes in real per ca pita GDP (i.e., $b_{3}=0$ ), which some researchers a rgue is unrea listic, especially post-GFC. Our key finding that policy multipliers ha ve fallen post-GFC is robust to these alternative identifying a ssumptions. The empirical results a re available from the authors upon request.

${ }^{16}$ See Oulia ris, Pa ga na nd Restro (2018, Section 7.4.3) for a detailed explanation of the a pproach.
} 
The historical decompositions for the pre- and post-crisis models are shown in Figures 8 and 9 for the periods 2002-2007 and 2014-2019 respectively. Ranked in terms of their average contribution to real GDP in absolute terms, the historical shocks to debt (negative), taxes (positive) and the real interest rate (negative) were the three most important drivers of real GDP per capita during 2002-2004 (Figure 8, Panel A). Shocks to taxes (negative), the debtratio (positive), and Federal Reserve asset holdings (negative) were the top three drivers of real GDP per capita during 2005-2007 (Panel B). For the post-crisis period, the top three drivers of real GDP per capita during 2014-2016 were the historical shocks to the real interest rate (negative contribution), tax es (positive) and Federal Reserve asset holdings (negative) (Figure 9, Panel A). Shocks to taxes (positive), Federal Reserve asset holdings (negative), and debt (negative) had the largest impact during 2017-2019 (Panel B).

The historical decomposition is a non-linear function of the estimated structural shocks and the estimated coefficients of the SVECM, making precise comparisons across periods difficult. Running a simple linear regression of each historical decomposition for real GDP per capita on its corresponding structural shock provides an estimate of the average sensitivity of the decomposition to the structural shock. These parameter estimates are presented in Table 2. We also tested whether there was a structural break in these estimates pre- and post-crisis, using the standard Chow Test, assuming a break point at 2008Q1. The results confirm that there have been significant changes in the pre- and post-crisis importance of specific structural shocks, and hence the corresponding multipliers. In particular, the average sensitivity of real GDP per capita to primary expenditure, tax es, and Federal Reserve asset holdings shocks have declined post-crisis, and this result is statistically significant. The sensitivity of real GDP per capita to real interest rates shocks has increased significantly and the increase is statistically significant.

Simple averages of the structural shocks driving the historical decompositions are shown in Table 3. The largest three shocks pre-crisis on average, ranked in absolute terms, came from the debt-to-GDP ratio, the real interest rate, and taxes. The ranking post-crisis was the debtto-GDP ratio, the real interest rate, and Federal Reserve asset holdings.

Table 4 shows the contribution of the average shocks to real GDP per capita, obtained by multiplying each average shock in Table 3 by the corresponding sensitivity of real GDP

presented in Table 2 The results suggest that the strongest drivers of real GDP per capita precrisis were the shocks to the debt-to-GDP ratio (positive), taxes (negative) and primary expenditure (negative). Shocks to taxes (positive), Federal Reserve asset holdings (positive), and the debt-ratio (negative) were the dominant drivers of real GDP per capita post-crisis.

\section{IMPACT OF COVID-19 MEASURES}

In seeking to address the economic fallout from the COVID-19 lockdown measures imposed during April 2020, the U.S. federal government announced a debt-financed stimulus package of approximately 2.4 trillion dollars, representing a 27 percent increase in government expenditure (or 9 percent of GDP). The Federal Reserve also resumed its asset purchase 
program, raising assets relative to GDP from 18 percent at the end of 2019 to 19.2 percent by the end of the first quarter of 2020. We now use the pre- and post-crisis models to estimate the incremental impact of these measures on real GDP growth for 8 quarters. We assume that the increase in government expenditure is spread equally over the first 4 quarters, and that the Federal Reserve's actions occurred entirely in the first quarter.

Figure 10 shows the expected impact of these policy actions on GDP relative to the baseline using the post-crisis estimates (i.e., the level of GDP assuming there was no increase in government spending or in Federal Reserve asset holdings). It also shows the increase in real GDP per capita assuming the pre-crisis model estimates applied post-crisis. On balance, the combined effect of the staggered increase in government expenditure and Federal Reserve asset purchases on real GDP per capita is less than 0.65 percentage points in the first quarter using the post-crisis model, rising to 2.5 percent after 5 quarters. The corresponding precrisis increments would have been around 1 percent and 3 percent respectively, demonstrating the reduced effectiveness of the COVID-19 stimulus measures using postGFC crisis multipliers. 
Figure 7. U.S. Multiplier for Real GDP Per Capita using Expanded Model

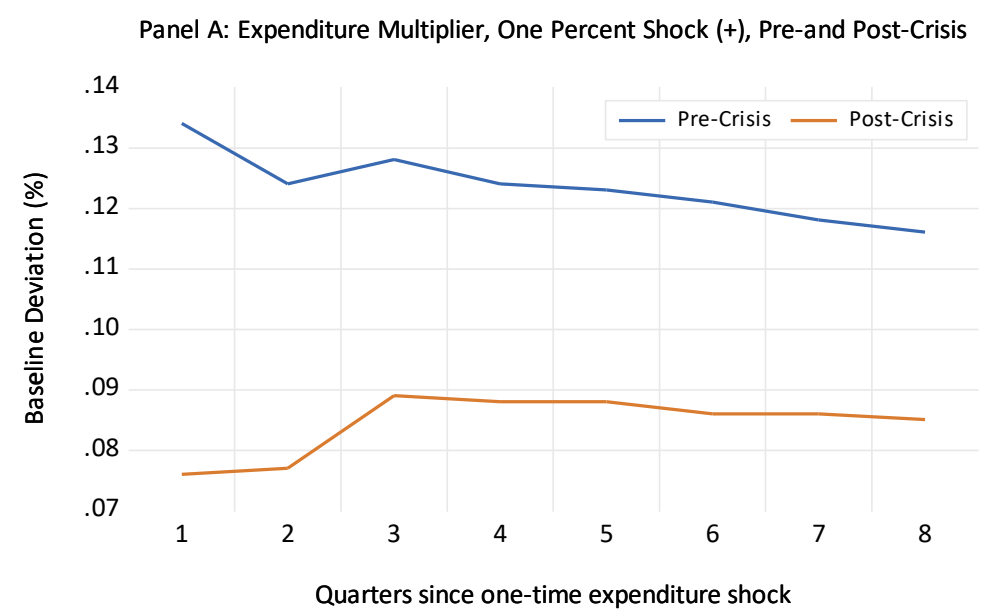

Panel C: Federal Reserve Asset Multiplier, One Percent Shock (+), Pre-and Post-Crisis .050

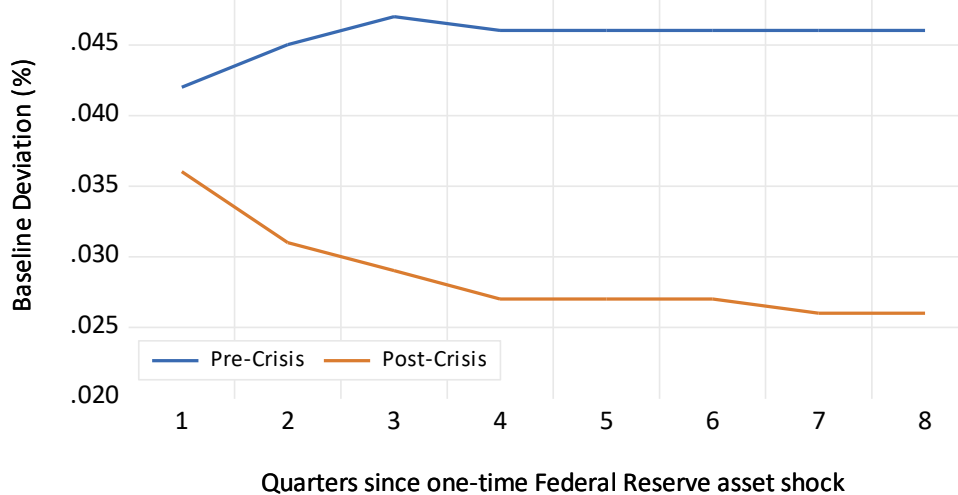

Panel B: Taxation Multiplier, One Percent Shock (+), Pre-and Post-Crisis

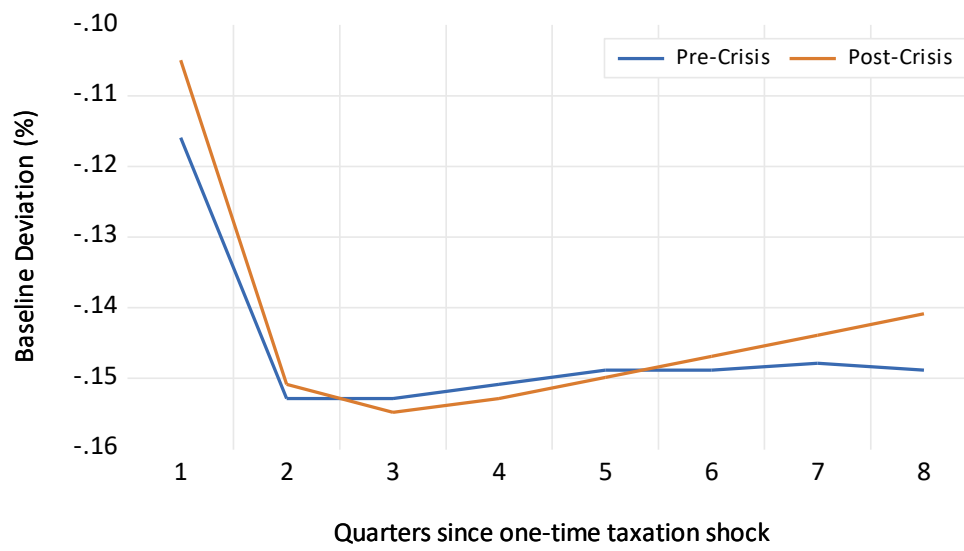

Panel D: Real Interest Rate Multiplier, 100 Basis Point Shock (+), Pre-and Post-Crisis .00

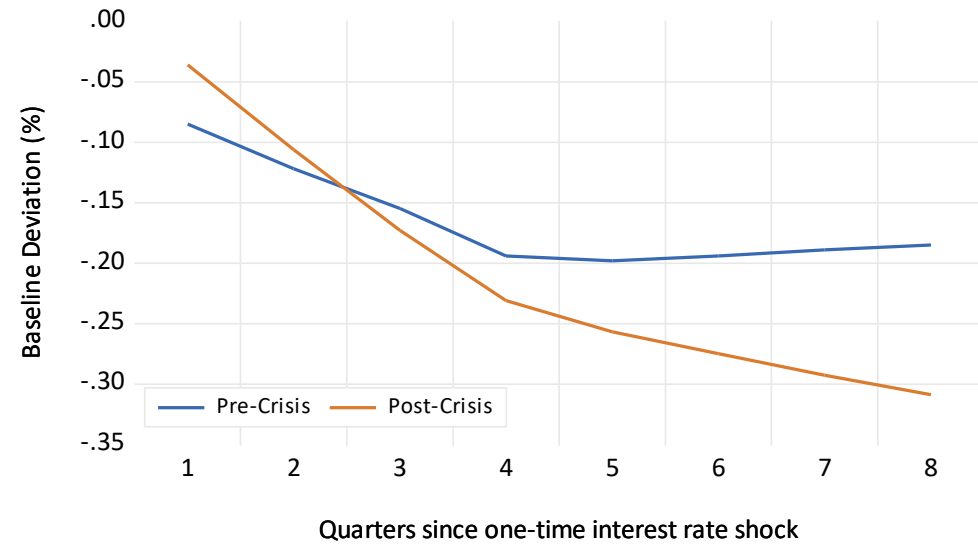


Figure 8. Historical Decomposition of Real GDP from its Baseline, 2002Q1-2007Q4

Panel A: 2002Q1-2004Q4

.008

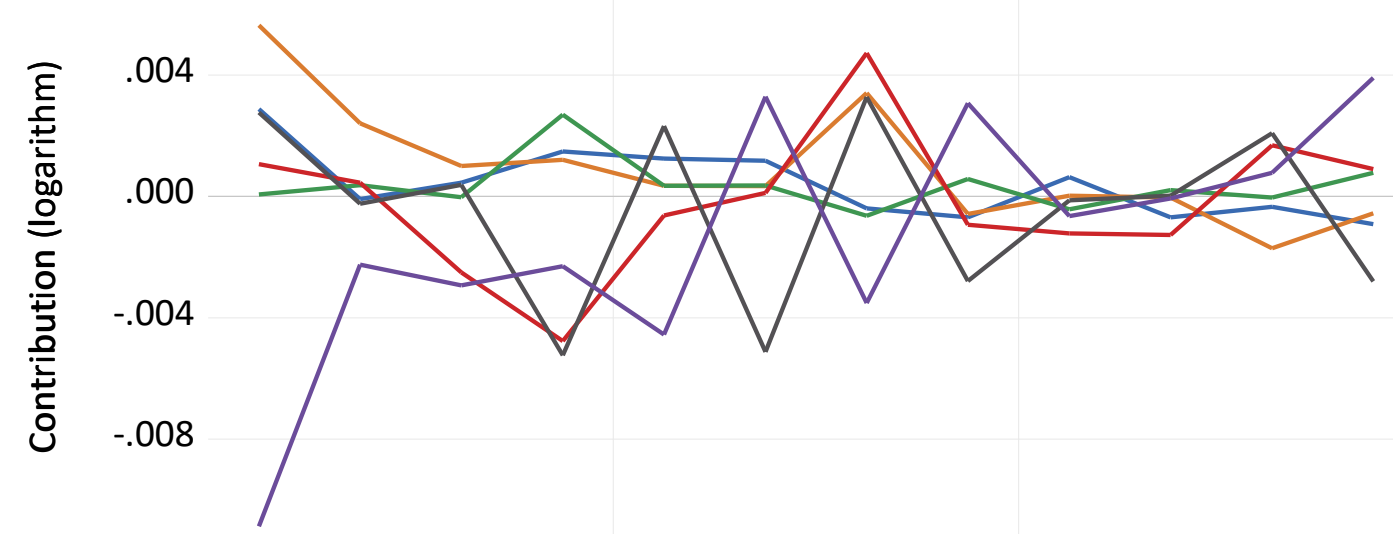

$-.012$

$\begin{array}{llllclllll}\text { I II III } & \text { IV } & \text { I } & \text { II } & \text { III } & \text { IV } & \text { I } & \text { II III } & \text { IV } \\ 2002 & & & 2003 & & & 2004 & \end{array}$

Primary Expenditure

Taxes

Federal Reserve Asset Holdings

Real GDP per capita

Real Interest Rate

Debt-to-GDP ratio

Panel B: 2005Q1-2007Q4

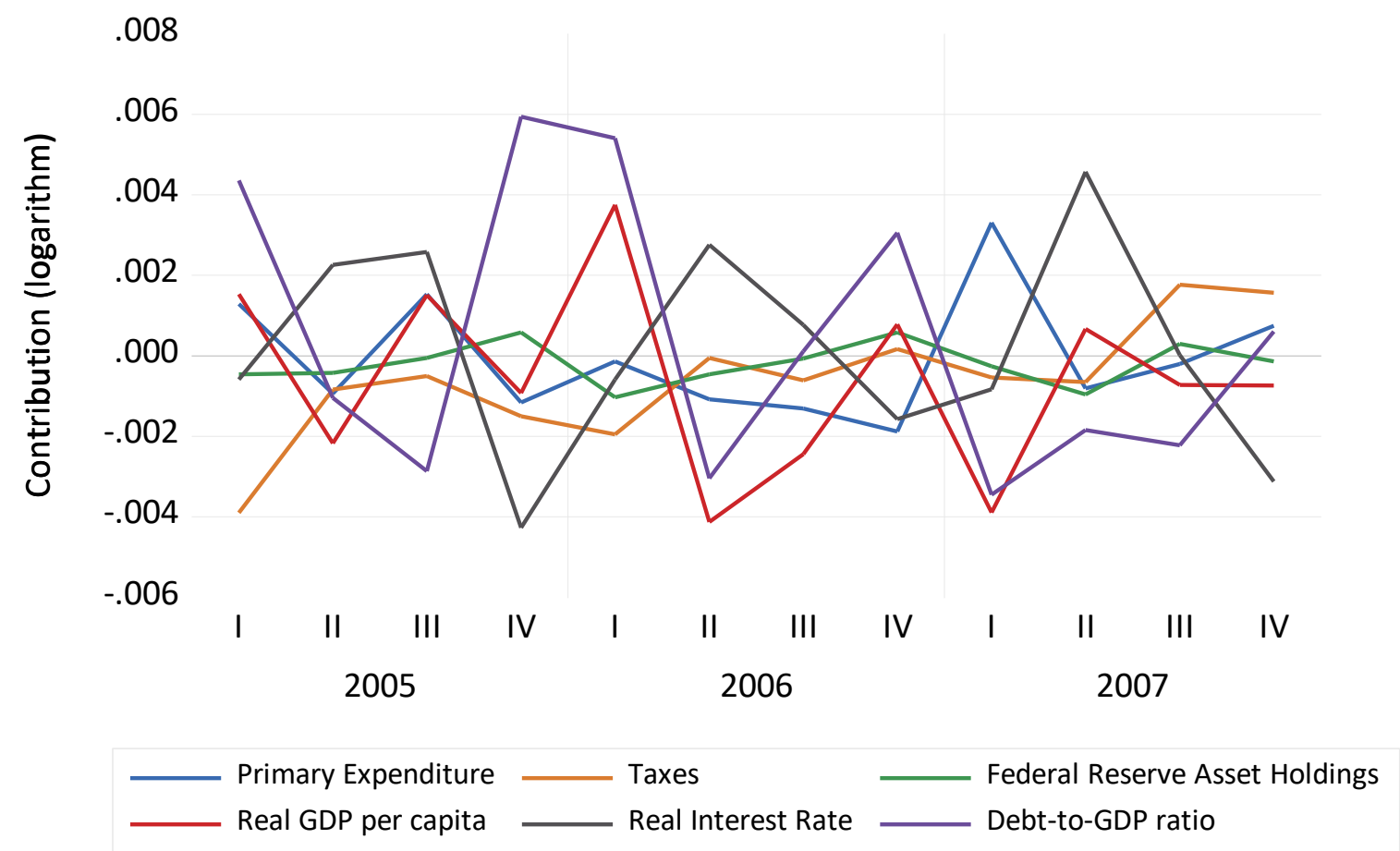

CInternational Monetary Fund. Not for Redistribution 
Figure 9. Historical Decomposition of Real GDP from its Baseline, 2014Q1-2019Q4

Panel A: 2014Q1-2016Q4

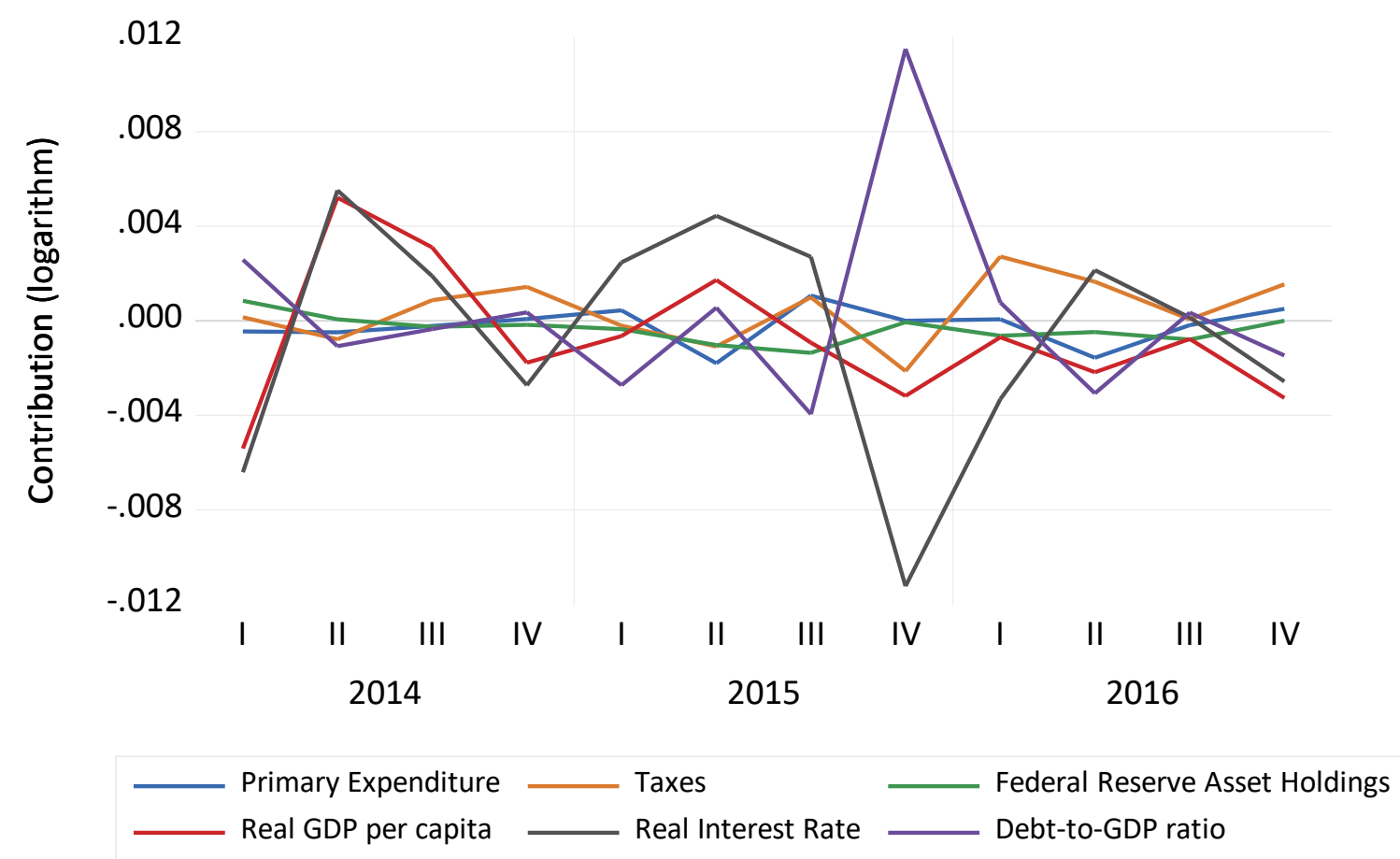

Panel B: 2017Q1-2019Q4

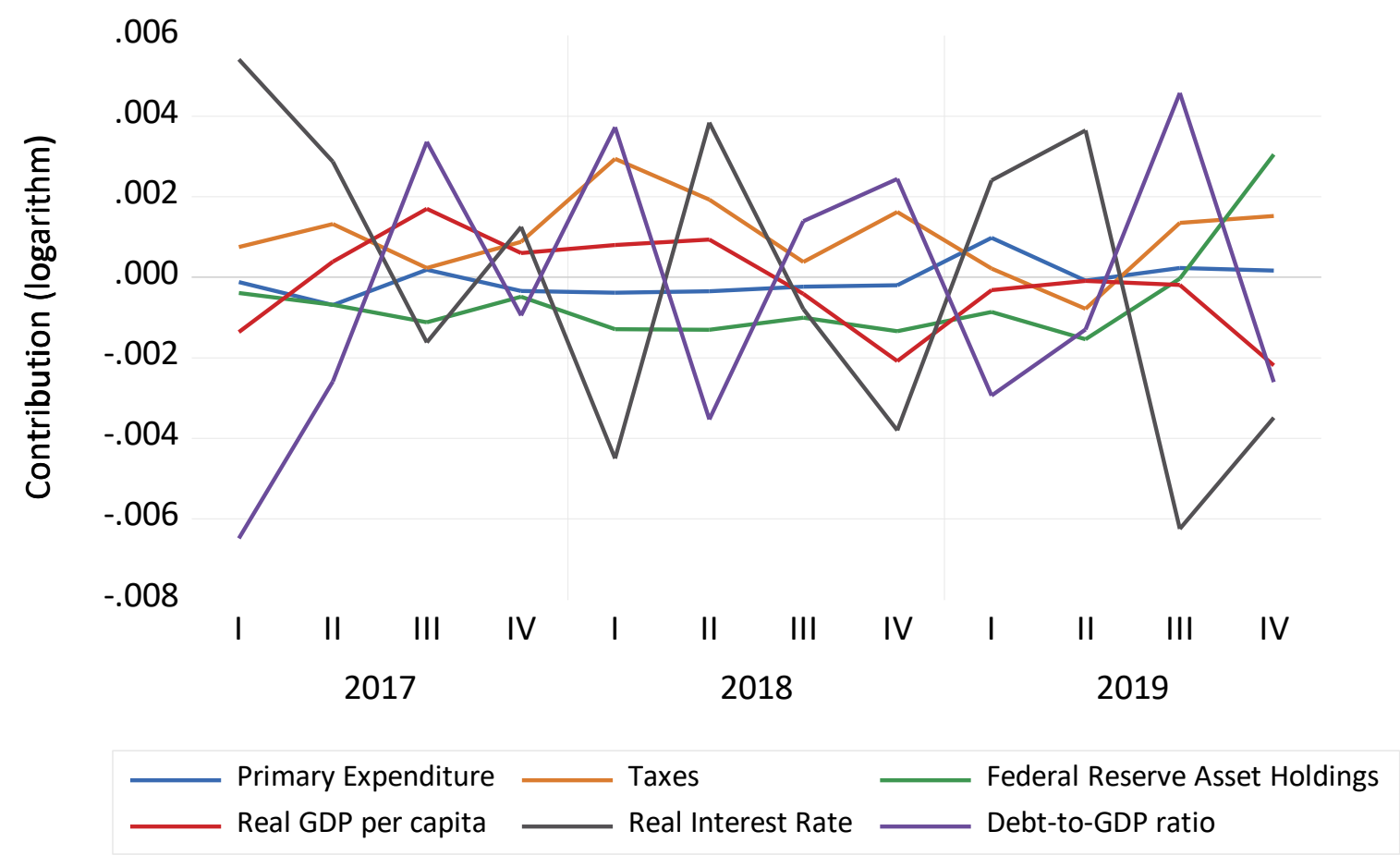

(CInternational Monetary Fund. Not for Redistribution 
Figure 10. Impact of U.S. Government 2020 COVID-19 Measures on Real GDP, as of May 21, 2020.

Expenditure (+27\%) and FED Asset Holdings (+7\%)

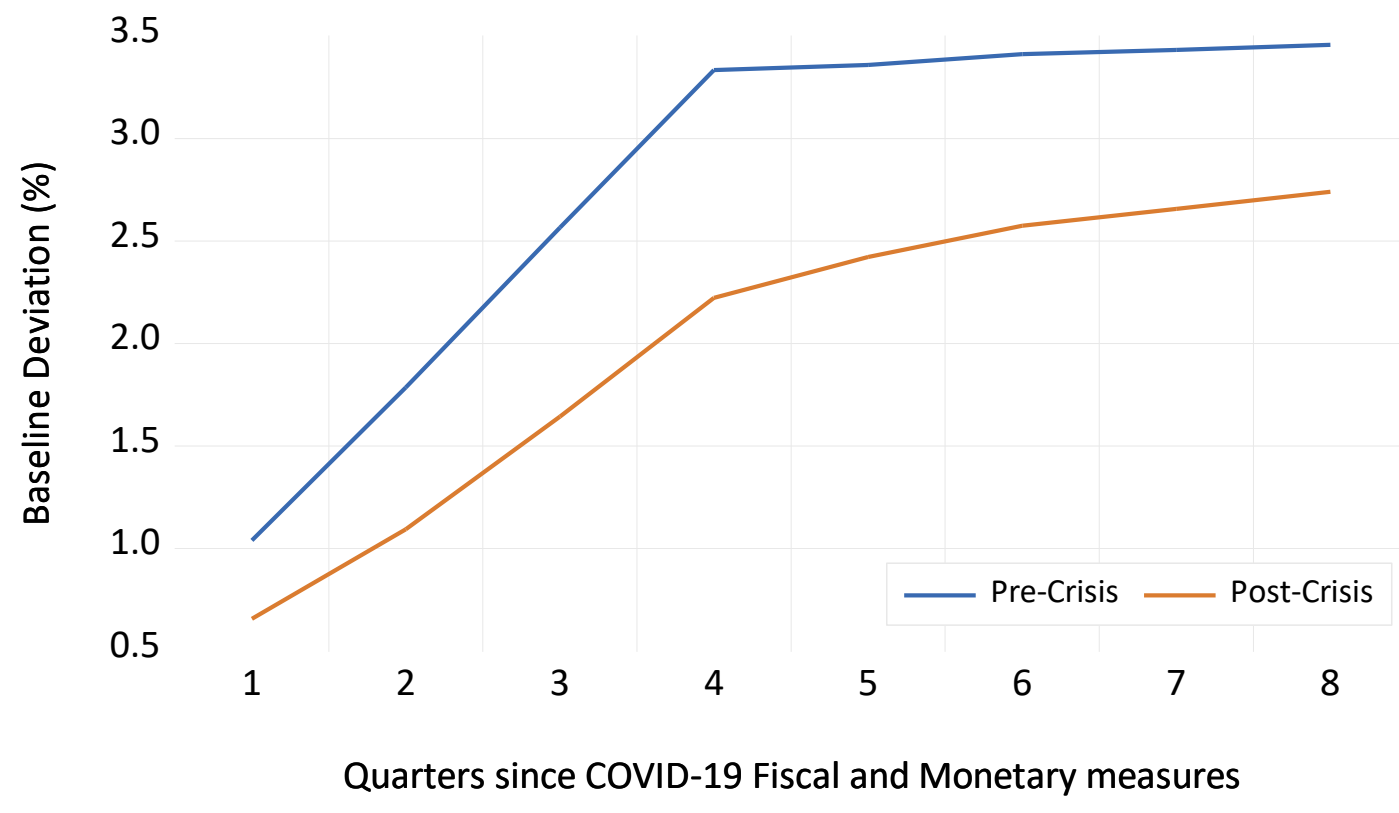

CInternational Monetary Fund. Not for Redistribution 
Table 1. F-Statistics for the Null Hypothesis of No Change in the Policy Multipliers Pre- and Post-GFC

\begin{tabular}{|l|c|c|}
\hline \multicolumn{1}{|c|}{ Structural Shock } & F-statistic & p-Value \\
\hline Primary Expenditure & 262.6048 & $0.0000^{*}$ \\
\hline Taxes & 164.6404 & $0.0000^{*}$ \\
\hline Federal Reserve Assets Ratio & 164.0191 & $0.0000^{*}$ \\
\hline Real Interest Rate (basis points) & 162.4467 & $0.0000^{*}$ \\
\hline Debt-to-GDP Ratio (percent) & 247.5926 & $0.0000^{*}$ \\
\hline
\end{tabular}

An a sterisk indicates that there is a statistically significant difference in the impulse response functions (i.e. the multipliers) pre-and post-GFC.

Table 2. Simple Regression Coefficient of the Historical Decomposition of Real GDP Per Capita Against Individual Structural Shocks

\begin{tabular}{|l|c|c|c|}
\hline \multicolumn{1}{|c|}{ Structural Shock } & 1996Q1-2007Q4 & 2008Q1-2019Q4 & p-Value \\
\hline Primary Expenditure & 0.1396 & 0.0759 & $0.0000^{*}$ \\
\hline Taxes & -0.1162 & -0.1054 & $0.0000^{*}$ \\
\hline Federal Reserve Assets Ratio & 0.0422 & 0.0360 & $0.0000^{*}$ \\
\hline Real Interest Rate (basis points) & 0.0011 & 0.0025 & $0.0001^{*}$ \\
\hline Debt-to-GDP Ratio (percent) & -0.0021 & -0.0007 & 0.1686 \\
\hline
\end{tabular}

An a sterisk indicates that there is a sta tistically significant difference in the estimates across the two periods, with the p-va lue of the test (theChow break point test postulating a break point at 2008Q1) shown in column 4. The null hypothesis is that there was no change in the parameter in the pre-and post-crisis period.

Table 3. Simple Average of Estimated Structural Shocks (logarithm)

\begin{tabular}{|l|c|c|}
\hline \multicolumn{1}{|c|}{ Structural Shock } & 1996Q1-2007Q4 & 2008Q1-2019Q4 \\
\hline Primary Expenditure & $-1.1860 \mathrm{E}-03$ & $-1.6360 \mathrm{E}-03$ \\
\hline Taxes & $2.1590 \mathrm{E}-03$ & $-7.0010 \mathrm{E}-03$ \\
\hline Federal Reserve Assets Ratio & $6.2800 \mathrm{E}-04$ & $2.0276 \mathrm{E}-02$ \\
\hline Real Interest Rate (basis points) & $1.7182 \mathrm{E}-02$ & $-9.1598 \mathrm{E}-02$ \\
\hline Debt-to-GDP Ratio (percent) & $-4.2229 \mathrm{E}-01$ & $6.9703 \mathrm{E}-01$ \\
\hline
\end{tabular}

The estimated structural shocks are defined as the actual value of the variable of interest (e.g., primary expenditure) minus its baseline value.

Table 4. Contribution of Average Structural Shocks to Real GDP Per Capita

\begin{tabular}{|l|c|c|}
\hline \multicolumn{1}{|c|}{ Structural Shock } & 1996Q1-2007Q4 & 2008Q1-2019Q4 \\
\hline Primary Expenditure & $-1.6558 \mathrm{E}-04$ & $-1.2424 \mathrm{E}-04$ \\
\hline Taxes & $-2.5087 \mathrm{E}-04$ & $7.3791 \mathrm{E}-04$ \\
\hline Federal Reserve Assets Ratio & $2.6483 \mathrm{E}-05$ & $7.2982 \mathrm{E}-04$ \\
\hline Real Interest Rate (basis points) & $1.8724 \mathrm{E}-05$ & $-2.2609 \mathrm{E}-04$ \\
\hline Debt-to-GDP Ratio (percent) & $8.8374 \mathrm{E}-04$ & $-4.7848 \mathrm{E}-04$ \\
\hline
\end{tabular}

These values are obtained by multiplying the values in Ta ble 2 and Table 3 . 


\section{CONCLUSION}

We studied the change in the fiscal multipliers in the U.S. relative to their pre-crisis levels using an expanded Blanchard-Perotti model to allow for the dynamic effects of shocks in the central bank balance sheet, real interest rates and debt levels on real GDP per capita. The elevated debt levels and significantly larger central bank balance sheets have an impact on the strength of the multipliers. We found evidence that expenditure and tax multipliers have fallen post-crisis in the U.S., implying that the effectiveness of fiscal policy has declined. The analysis also shows that the effectiveness of unconventional monetary policy via asset purchases is not as strong as expected. Dealing with a crisis is becoming more and more costly, despite the current low interest rate environment. 


\section{REFERENCES}

Blanchard, O. and R. Perotti (2002), An Empirical Characterization Of The Dynamic Effects Of Changes In Government Spending And Taxes On Output," The Quarterly Journal of Economics, 117, 1329-1368.

Burbridge, J. and A. Harrison (1985). "A Historical Decomposition of the Great Depression to Determine the Role of Money," Journal of Monetary Econometrics, 16, 4554.

Checherita, C and P. Rother (2010). The Impact of High and Growing Government debt on Economic Growth. An Empirical Investigation for the Euro Area. ECB WP 1237.de Rugy, V. and J. Salmon (2020) "Debt and Growth: A Decade of Studies", https://www.mercatus.org/publications/government-spending/debt-and-growth-decadestudies

Ouliaris, S., Pagan, A.R. and J. Restrepo (2018) "Quantitative Macroeconomic Modeling with Structural Vector Autoregressions-An EViews Implementation”, download from http://www.eviews.com/StructVAR/structvar.html

Pagan, A. R. and M. H. Pesaran (2008), Econometric Analysis of Structural Systems with Permanent and Transitory Shocks," Journal of Economic Dynamics and Control, 32, 33763395.

Ramey, V. (2018). "Government Spending Multipliers in Good Times and in Bad:

Evidence from US Historical Data”, Journal of Political Economy, 126, no. 2, 850-900.

Ramey, V. (2019). "Ten Years After the Financial Crisis: What Have We Learned from the Renaissance in Fiscal Research?", Journal of Economic Perspectives, 33, no. 2, 89-1 14.

Staff Reports for the U.S. Article IV Consultations, 2008-2018, International Monetary Fund. 


\section{ANNEX 1}

Table A1. Summary of policies post-GFC in the U.S. ${ }^{17}$

\begin{tabular}{|c|c|c|}
\hline Year & Monetary Policy & Fiscal Policy \\
\hline 2008 & $\begin{array}{l}\text { Fed lowered its target rate to a range of 0- } \\
25 \text { basis points. } \\
\text { Fed's balance sheet doubled in size to over } \\
\$ 2 \text { trillion ( } 15 \text { percent of GDP), with the } \\
\text { potential to exceed } \$ 4 \text { trillion ( } 30 \text { percent } \\
\text { of GDP )if facilities reached their caps. }\end{array}$ & \\
\hline 2009 & $\begin{array}{l}\text { March: Fed announced stepped up } \\
\text { securities purchases, including mortgage } \\
\text { and agency securities as well as longer term } \\
\text { Treasuries }\end{array}$ & $\begin{array}{l}\text { Fiscal stimulus totaling over } 5 \text { percent of one } \\
\text { year's GDP over } 2009-2011 \text { (tax cuts, } \\
\text { infrastructure spending, and aid to states and } \\
\text { the vulnerable). } \\
\text { Deficits in } 2009 / 10 \text { and } 2010 / 11 \text { will average } \\
12 \frac{1}{2} \text { percent of GDP, pushing up gross federal } \\
\text { government debt held by the public by almost } \\
30 \text { percent of GDP to about } 70 \text { percent of GDP. } \\
\text { Gross financing requirements } \\
\text { will rise sharply to some } 30 \text { percent of GDP. } \\
\text { Key fiscal risks include costs of financial rescue } \\
\text { operations (including those accrued by the } \\
\text { Fed), as well as possible calls to support } \\
\text { private } \\
\text { defined benefit pensions and state finances. }\end{array}$ \\
\hline 2010 & $\begin{array}{l}\text { Fed wound down most of its emergency } \\
\text { facilities (e.g. theTerm Asset Backed } \\
\text { Securities Lending Facility), and ended the } \\
\text { \$1.7 trillion Large-Scale Asset Purchase } \\
\text { Program } \\
\text { Second round of unconventional easing } \\
\text { beginning in the Fall in response to the } \\
\text { weakening of inflation and growth }\end{array}$ & $\begin{array}{l}\text { Under current policies, fe deral debt held by } \\
\text { the public could rise from } 64 \text { percent to } 95 \\
\text { percent of GDP by } 2020 \text {. Thereafter, the rising } \\
\text { impact of population aging and health-care } \\
\text { inflation would push debt higher, swelling over } \\
135 \text { percent of GDP by } 2030 \text { and continuing to } \\
\text { trend up. }\end{array}$ \\
\hline 2011 & $\begin{array}{l}\text { Near-zero policy rates and clear } \\
\text { communication that conditions would likely } \\
\text { warrant exceptionally low policy rates for } \\
\text { an extended period } \\
\text { September: Fed launched "Operation } \\
\text { Twist," comprising purchases of up to } \$ 400 \\
\text { billion in Treasury securities with remaining } \\
\text { maturities of 6-30years and sales of an } \\
\text { equal amount of securities with remaining } \\
\text { maturities of } 3 \text { years or less, to be } \\
\text { completed by June } 2012 \text {. It started }\end{array}$ & $\begin{array}{l}\text { The Budget Control Act adopted in the } \\
\text { summer capped discretionary spending. } \\
\text { Savings in the form of deep automatic } \\
\text { spending cuts ("sequester") are scheduled to } \\
\text { take effect starting from } 2013 \text {. The overall } \\
\text { savings from the discretionaryspending caps } \\
\text { and sequester would be significant ( } \$ 2.1 \\
\text { trillion over } 10 \text { years), but insufficient to } \\
\text { stabilize the debt ratio. }\end{array}$ \\
\hline
\end{tabular}

${ }^{17}$ The information in this table is from IMF StaffReports for the U.S. Article IV Consultations during 20082018. 


\begin{tabular}{|c|c|c|}
\hline & $\begin{array}{l}\text { reinvesting principal payments on agency } \\
\text { debt and MBS into agency MBS. }\end{array}$ & \\
\hline 2012 & $\begin{array}{l}\text { Fed stated that economic conditions were } \\
\text { likely to warrant low rates at least through } \\
\text { late } 2014 . \\
\text { Expiration of "Operation Twist" in } \\
\text { December. } \\
\text { On June } 20 \text { the Fed announced that it } \\
\text { would continue through end-2012 its } \\
\text { program to extend the average maturity of } \\
\text { its securities holdings. This will entail sales } \\
\text { or redemptions of about } \$ 267 \text { billion in } \\
\text { shorter-term securities, and purchases of } \\
\text { longer-maturity Treasury securities of an } \\
\text { equal amount, by the end of } 2012 \text {. Once } \\
\text { the maturity extension program is } \\
\text { completed, the Federal Reserve will hold } \\
\text { almost no securities maturing through } \\
\text { January } 2016 \text {. } \\
\text { Fed announced open-ended outright } \\
\text { purchases of long-term Treasuries at an } \\
\text { initial pace of } \$ 45 \text { billion a month. These } \\
\text { purchases were in addition to open-ended } \\
\text { purchases of mortgage backed securities } \\
\text { (MBS) at a pace of } \$ 40 \text { billion a month, } \\
\text { which began in September } 2012 \text {. } \\
\text { December meeting of the FOMC: the Fed } \\
\text { committed to keeping the federal funds } \\
\text { rate close to zero at least as long as the } \\
\text { unemployment rate remains above } 61 / 2 \\
\text { percent, inflation projected } 1-2 \text { years } \\
\text { ahead is not above } 21 / 2 \text { percent, and longer- } \\
\text { term inflation expectations remain well- } \\
\text { anchored. } \\
\text { The highly accommodative monetary policy } \\
\text { stance provided key support to the } \\
\text { recovery. Based on staff estimates, the } \\
\text { lower long-term yields from } \\
\text { unconventional policies resulted in a } \\
\text { stimulus equivalent to a federal funds rate } \\
\text { easing of roughly } 250 \text { basis points as of } \\
\text { end- } 2012 \text {. }\end{array}$ & \\
\hline 2013 & & $\begin{array}{l}\text { The pace of fiscal consolidation accelerated. } \\
\text { Congress allowed the automatic across-the } \\
\text { board spending cuts ("sequester") to } \\
\text { materialize from March. } \\
\text { In combination with other measures, such as } \\
\text { higher marginal rates for upper-income }\end{array}$ \\
\hline
\end{tabular}




\begin{tabular}{|c|c|c|}
\hline & & $\begin{array}{l}\text { taxpayers and the expiration of the payroll tax } \\
\text { cut, as well as stronger-than-expected revenue } \\
\text { collections, the structural primary withdrawal } \\
\text { is estimated to have increased to about } 2 \frac{1}{2} \\
\text { percent of GDP this year, from } 1 \frac{1}{4} \text { percent in } \\
2012 \text {. }\end{array}$ \\
\hline 2014 & $\begin{array}{l}\text { The median forecast of participants in } \\
\text { FOMC deliberations indicates that the fed } \\
\text { funds rate is expected to lift-off from zero } \\
\text { by mid-2015, with a gradual path upward } \\
\text { toward a } 3.75 \text { percent longterm level. . } \\
\text { However, even with this path for policy } \\
\text { rates, the economyis expected to reach full } \\
\text { employment slowly and inflation pressures } \\
\text { are forecast to remain muted. There is } \\
\text { some scope for policy rates to stay at zero } \\
\text { for longer while still keeping inflation under } \\
2 \text { percent. }\end{array}$ & $\begin{array}{l}\text { Consolidation in } 2011-13 \text { was stronger than } \\
\text { had been earlier anticipated (the federal } \\
\text { primary structural deficit declined by } 11 \% 4 \\
\text { percent of GDP more than was predicted in } \\
2011 \text { ). } \\
\text { The outlook for potential growth has } \\
\text { worsened, lowering future federal revenues } \\
\text { and compounding the long-term fiscal } \\
\text { sustainability challenge. As a result, under } \\
\text { current policies, after stabilizing in } 2015-18 \text {, } \\
\text { the debt-to-GDP ratio is expected to begin } \\
\text { rising again as aging-related pressures assert } \\
\text { themselves and interest ratesnormalize. }\end{array}$ \\
\hline 2015 & $\begin{array}{l}\text { Fed's first rate increase in almost nine } \\
\text { years, carefully prepared and telegraphed. }\end{array}$ & $\begin{array}{l}\text { Budget proposals for FY2016: } \\
\text { The budget is forecast by the Office of } \\
\text { Management and Budget to deliver a } \\
\text { stable federal government deficit of around } \\
21 / 2 \text { percent of GDP through the } 10 \text { year budget } \\
\text { window and stabilize the fe deral debt at about } \\
73 \text { percent of GDP by } 2025 \text {. To achieve this, } \\
\text { the proposal outlines savings in healthcare } \\
\text { spending, increased revenues from lower } \\
\text { personal income tax deductions for higher } \\
\text { income individuals, changes to the business } \\
\text { tax code, an end to sequestration, funds to } \\
\text { augment education and infrastructure } \\
\text { programs, and immigration reform. } \\
\text { The congressional budget blueprint aims to } \\
\text { balance the budget in } 10 \text { years without revenu } \\
\text { increases and through significant cuts to } \\
\text { discretionary, non-defense spending }\end{array}$ \\
\hline 2016 & $\begin{array}{l}\text { Since the first rate increase in December } \\
2015, \text { the predicted pace of subsequent } \\
\text { rate increases } \\
\text { has slowed (in both the FOMC and market's } \\
\text { expectations). Despite a string of strong } \\
\text { labor } \\
\text { market data, there has been concern } \\
\text { around weak activity and, more recently, } \\
\text { jobs data, recurrent bouts of financial } \\
\text { market volatility, and diminishing global } \\
\text { prospects. }\end{array}$ & $\begin{array}{l}\text { Near-term fiscal policy has been well- } \\
\text { calibrated to the prevailing economic } \\
\text { circumstances. At the general government } \\
\text { level, the change in the structural primary } \\
\text { balance is } \\
\text { expected to be }-1 / 2 \text { and } 0.1 \text { percent of GDP in } \\
2016 \text { and } 2017, \text { respectively. This should be } \\
\text { mildly supportive of growth, particularly if } \\
\text { gauged against the fiscal contractions (of } \\
\text { around } 1 / 2 \text { percent of GDP) experienced in } \\
2014-15 \text {. From a macroeconomic perspective, } \\
\text { both near-term fiscal and monetarypolicies } \\
\text { appear consistent with the need to provide } \\
\text { modest support to the economy as it }\end{array}$ \\
\hline
\end{tabular}




\begin{tabular}{|c|c|c|}
\hline & & $\begin{array}{l}\text { transitions toward full employment in the face } \\
\text { of global and domestic headwinds. } \\
\text { Fiscal uncertainties have been diminished by } \\
\text { the passage of: } \\
\text { ? The Bipartisan Budget Act of } 2015 \text { which } \\
\text { suspended the debt ceiling until March } 2017 \\
\text { and avoided the risk of government shutdown } \\
\text { by locking in appropriations for } 2016 \text { and } \\
\text { 2017. } \\
\text { ? Protecting Americans from Tax Hikes Act that } \\
\text { lowered tax revenues by } 31 / 2 \text { percent of GDP } \\
\text { over the next } 10 \text { years. Among the many } \\
\text { provisions, the bill made permanent the } \\
\text { enhanced child tax credit, the American } \\
\text { Opportunitytax credit for college tuition, and } \\
\text { the improvements to the earned income tax } \\
\text { credit (i.e. the expansion to larger families and } \\
\text { removal of the marriage penalty). The bill also } \\
\text { made permanent the research and } \\
\text { experimentation credit for corporations (which } \\
\text { had been temporarily extended } 15 \text { times since } \\
\text { 1985). } \\
\text { ? Fixing America's Surface Transportation Act } \\
\text { that commits US\$ } 305 \text { billion to surface } \\
\text { transportation for the next } 4 \text { years and } \\
\text { provides some degree of stability to states in } \\
\text { planning projects that are co-financed with } \\
\text { federal resources. }\end{array}$ \\
\hline 2017 & $\begin{array}{l}\text { Fed holdings of securities are expected to } \\
\text { decline in a gradual and pre dictable } \\
\text { manner and the federal funds rate would } \\
\text { be the primary means for adjusting the } \\
\text { stance of monetary policy. A material } \\
\text { reduction in the economic outlook that } \\
\text { warranted a sizable reduction in the fe deral } \\
\text { funds rate could be accompanied by a } \\
\text { resumption of reinvestment of principal } \\
\text { payments. However, under the baseline } \\
\text { outlook, the intention is for changes to the } \\
\text { balance sheet to be quietlyoperating in the } \\
\text { background over the next several years } \\
\text { with minimal effects on financial } \\
\text { conditions. The future level of reserves in } \\
\text { the banking system would be appreciably } \\
\text { below that seen in recent years but larger } \\
\text { than before the financial crisis. }\end{array}$ & $\begin{array}{l}\text { The administration's budget proposes an } \\
\text { expenditure-based medium-term fiscal } \\
\text { consolidation. Under the authorities' budget, } \\
\text { the federal primarybalance is forecast to go } \\
\text { from a } 1.9 \text { percent of GDP deficit to a } 2.1 \\
\text { percent of GDP surplus over the next } 10 \text { years. } \\
\text { This includes: } \\
\text { - A reduction in both non-defense spending } \\
\text { and defense outlays as a share of GDP. The } \\
\text { nondefense spending reductions are } \\
\text { concentrated in two broad areas: a downsizing } \\
\text { of line agencies (outside of defense and } \\
\text { security) and reductions in spending on safety } \\
\text { net programs (including funding for Medicaid } \\
\text { and food stamps as well as tightening eligibility } \\
\text { for earned income and child tax credits and } \\
\text { disability insurance). } \\
\text { - A tax reform that is designed to improve } \\
\text { efficiency, lower marginal rates, and broaden } \\
\text { the base while leaving the federal revenue- } \\
\text { GDP ratio broadly unchanged. }\end{array}$ \\
\hline
\end{tabular}




\begin{tabular}{|c|c|c|}
\hline & & $\begin{array}{l}\text { - An extremely optimistic real GDP growth } \\
\text { assumption, that rises to } 3 \text { percent by } 2021 \\
\text { and remains at that level over the medium } \\
\text { term. } \\
\text { The administration is committed to increasing } \\
\text { defense, infrastructure } \\
\text { and security spending in the upcoming fiscal } \\
\text { year and to lower most other spending items, } \\
\text { outside of social security and Medicare. There } \\
\text { is scope to reduce or eliminate programs with } \\
\text { limited effect on outcomes since there is } \\
\text { significant inefficiency and duplication in } \\
\text { existing federal spending. As part of this re- } \\
\text { examination of spending, efforts were being } \\
\text { made to devolve responsibilities and provide } \\
\text { states with greater flexibility in a range of } \\
\text { areas } \\
\text { (including Medicaid, social assistance } \\
\text { programs, and infrastructure provision). This } \\
\text { would allow states to innovate, find more } \\
\text { efficient solutions, and ultimately yield better } \\
\text { outcomes at a lower cost. The proposed } \\
\text { reductions in federal spending will encourage } \\
\text { a return to productive work and, as a result, } \\
\text { have positive implications for the income } \\
\text { distribution. }\end{array}$ \\
\hline 2018 & $\begin{array}{l}\text { Given the planned fiscal stimulus, the } \\
\text { Federal Reserve will need to } \\
\text { raise policy rates at a faster pace to achieve } \\
\text { its dual mandate. In executing its monetary } \\
\text { policy decisions, the Fed's continued } \\
\text { adherence to the principles of data } \\
\text { dependence and clear communication will } \\
\text { be vital. }\end{array}$ & $\begin{array}{l}\text { The combination of revenue losses from the } \\
\text { Tax Cuts and Jobs Act and the } \\
\text { approved increase in spending will create a } \\
\text { significant increase in the fiscal deficit in the } \\
\text { next few years. This will add to an already- } \\
\text { unsustainable public debt, contribute to a rise } \\
\text { in global imbalances, and increase risks of } \\
\text { future recession, with possibly negative } \\
\text { outward spillovers. } \\
\text { The combined effect of the administration's } \\
\text { tax cuts and increased defense and non } \\
\text { defense discretionary spending policies will } \\
\text { cause the federal government deficit to } \\
\text { exceed } 4.5 \text { percent of GDP by } 2019 \text {. The } \\
\text { demand stimulus is expected to raise output, } \\
\text { cumulatively, by } 1 \frac{1}{2} \text { percent by } 2020 \text {, pushing } \\
\text { the unemployment rate below } 3 \frac{1}{2} \text { percent. } \\
\text { The increase in the federal deficit will } \\
\text { exacerbate an alreadyunsustainable upward } \\
\text { dynamic in the public debt-to-GDP ratio. Even } \\
\text { with the planned, modest fiscal consolidation }\end{array}$ \\
\hline
\end{tabular}




\begin{tabular}{|l|l|l|}
\hline & $\begin{array}{l}\text { that is scheduled to startin 2020, the federal } \\
\text { debt will continue to climb, exceeding } 90 \\
\text { percent of annual GDP by 2024. }\end{array}$ \\
\hline
\end{tabular}

